\title{
Ethnoveterinary Plants Used by Tribal People in The Northern Tanzania
}

\section{Thobias Oddo Tomeka}

College of African Wildlife Management Mweka

Rudolf Mremi ( $\nabla$ rmremi@mwekawildlife.ac.tz )

College of African Wildlife Management Mweka https://orcid.org/0000-0002-1640-4806

Alodia Kanilwa Machumu

College of African Wildlife Management Mweka

John Sanya

College of African Wildlife Management Mweka

Alex Wilbard Kisingo

College of African Wildlife Management Mweka

\section{Research}

Keywords: Ethnoveterinary plants, Fidelity level, Frequency index, Informant consensus factor, livestock ailment

Posted Date: November 5th, 2020

DOl: https://doi.org/10.21203/rs.3.rs-100745/v1

License: (c) (i) This work is licensed under a Creative Commons Attribution 4.0 International License.

Read Full License 


\title{
Ethnoveterinary practices of medicinal plants used by tribal people in the Northern Tanzania
}

\author{
Thobias Tomeka ${ }^{1}$, Rudolf Mremi $^{l}{ }^{*}$, Alodia Machumu ${ }^{1}$, John Sanya ${ }^{l} \&$ Alex W. Kisingo ${ }^{l}$ \\ ${ }^{1}$ College of African Wildlife Management, Mweka P.O. Box 3031 Moshi, Tanzania \\ *Corresponding authore-mail: rmremi@mwekawildlife.ac.tz
}

\begin{abstract}
Background: Despite the increasing use of modern veterinary services to cater for livestock healthcare needs, traditional remedy remains a prominent complementary medical practice yet inadequately documented. This is especially so in areas of rural Tanzania where livestock diseases are rampant and modern veterinary services are insufficiently provided. This study, therefore, aims to understand and document the indigenous knowledge associated with the use ethnoveterinary plants in curing livestock ailments in the northern Tanzania.

Methods: Ethnobotanical data from livestock keepers were collected through structured and semistructured interviews. A total of 161 informants were selected from Hai, Moshi, Siha and Meru districts in northern Tanzania using snowball sampling technique. The fidelity level, frequency index, and informant consensus factor ere estimated from the data.
\end{abstract}

Results: We found a total of 54 ethnoveterinary plants belonging to 51 genera and 35 families used to treat 34 kinds of livestock ailments. About $59 \%$ of all medicinal plants examined during this study were extracted from the leaves, mainly prepared in crushed form - infusions (29\%) and administered orally (77\%). Further results show that $77.1 \%$ of the formulations were prepared by plant materials obtained from a single species while $22.9 \%$ were prepared from different species. Aloe vera (L.) Burm, and Aloe volkensii Engl. scored the highest frequency indices (40.5 each) for 
treating Newcastle in poultry, and anti-diarrhoea in cattle, respectively. The highest fidelity levels were found in Capsicum frutescens L. (100) and Kigelia Africana L. (100) both responsible for treating Newcastle in Chicken, and Ficus sycomorus (Lam.) Benth (100) for relieving birth complications in cattle. Newcastle and respiratory ailment categories had the highest informant consensus factor value of 0.92 with 103 use-reports, referring to the use of nine plant species.

Conclusions: The high use of such ethnoveterinary plant in treating livestock ailments highlights their veterinary importance and the need for government support for initiatives aimed at preserving this knowledge as an alternative healthcare practice for livestock in rural Tanzania.

Keywords: Ethnoveterinary plants, Fidelity level, Frequency index, Informant consensus factor, livestock ailment 


\section{Background}

Since time immemorial, medicinal plants have been used by tribal people to prevent and treat different livestock ailments [1,2]. Although there has been a shift from direct use of plant formulations to modern drugs for livestock healthcare, the latter remains a critical complementary ethnoveterinary practice in areas where infectious diseases are rampant and modern veterinary services are insufficiently provided [3,4]. Given their extensive range of knowledge in ethnomedicinal plants, tribal people remain the ultimate resource for retrieving this information for further discovery of modern drugs [5].

Several studies have assessed traditional knowledge associated with the use of plant medications to prevent and treat diseases in humans and animals [6-8]. While the focus of ethnobotanical studies in Tanzania has been on exploring the indigenous knowledge associated with utilization of medicinal plants for human healthcare, there have been few studies which attempt to examine ethnoveterinary practices in preventing or controlling livestock ailments. Ethnoveterinary studies are reported in other African countries including but not limited to: Namibia [9]; Ethiopia [10,11]; Zimbabwe [12]; Nigeria [13]; and Kenya [14].

Like in these countries, a few qualitative studies have shown that most small-scale farmers in Tanzania rely on traditional remedies for treating livestock ailments $[3,15,16]$. In rural areas where most small-scale farmers are found, veterinary services are limited due to a shortage of synthetic drugs, lack of skilled veterinarians, and insufficient financial capacity of farmers to pay for modern veterinary services. Because of this situation, the use of traditional medications is considered a prominent alternative medicine for treating various diseases in livestock [17]. Despite the increasing loss of plants and its importance in veterinary services $[18,19]$ in livestock keeping 
hotspots in Tanzania, the existing local knowledge which covers measures of uses of plant medications for livestock healthcare remains inadequately documented $[3,20]$. In this study, we aim to document local knowledge associated with ethnoveterinary plants and quantify the extent of their use through indices of fidelity, frequency, and informant consensus factor in the selected districts in Northern Tanzania. Searching for ways to preserve this ethnoveterinary knowledge is a cornerstone to discovering the healing activity of medicinal plants [21]. The findings from this study provide a scientific basis for future studies to evaluate the pharmacological efficacy of the reported ethnoveterinary plants [22]. Also, the ethnoveterinary knowledge of plants documented in this study can help in developing a conservation management plan of medicinal plants to ensure their sustainability.

\section{Methods}

\section{Study area description}

This ethnobotanical study was conducted in Moshi, Hai, Siha, and Meru districts situated in Northern Tanzania (Figure 1). These districts are characterized by diverse climatic conditions that support varieties of plant communities ranging from savanna to forests. These plant communities support myriads of plant species with curative properties. The four districts in which ethnobotanical sampling was conducted, border Kilimanjaro and Arusha National Parks, and forest reserves which are primary sources of wild medicinal plants for tribal people. The districts are dominated by Chagga, Maasai, Pare, and Meru communities who are either settled farmers in the highlands or pastoralists in the lowlands. A large proportion of farmers in these districts rely on modern drugs for prevention and control of various diseases in livestock. Despite this, ethnoveterinary herbal medications are still used as complementary remedies. 


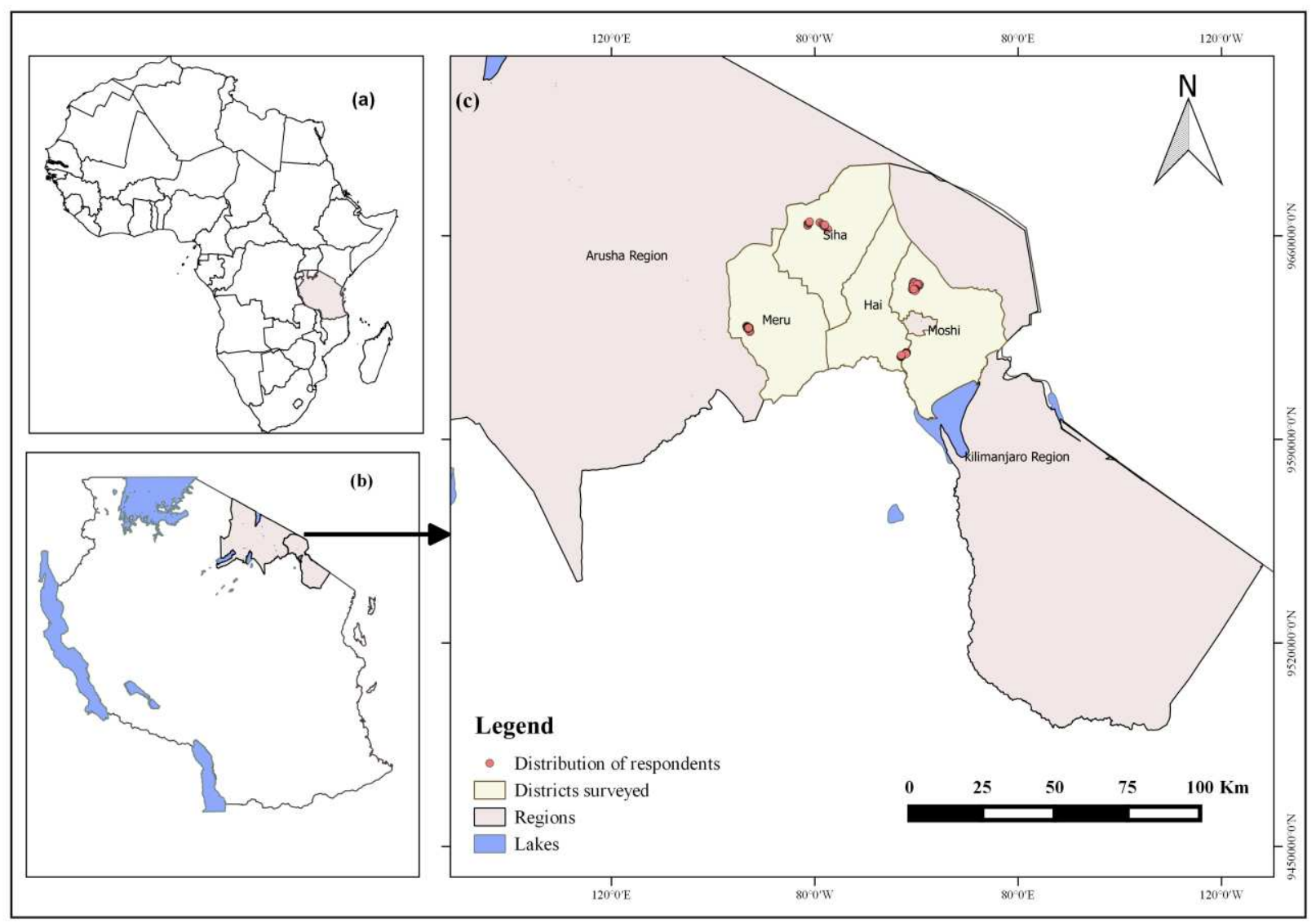

Figure 1. A Map of the study area showing study sites. (a) Location of Tanzania on the map of Africa; (b) Location of the surveyed area on the map of Tanzania (c) Distribution of respondents in Moshi, Hai, Siha and Meru districts in the Northern Tanzania.

\section{Data collection}

Ethnobotanical data were collected in Moshi, Hai, Siha and Meru districts using structured and semi-structured interviews with livestock keepers, traditional healers and veterinary officers as described by Alexiades [23]. The Snowball sampling technique was used to select respondents for providing knowledge and experience on how to use ethnoveterinary plants for veterinary purposes. We interviewed a total of 161 livestock keepers from the study area. In addition, we collected specimens and identified all reported ethnoveterinary plants species through direct observations in 
villages and nearby natural areas. Data collected during this study included local names of plants, parts of plants used, livestock species, and types of ailment treated, methods of dosage preparation, and mode of administering medications to livestock. The nomenclature of the most reported ethnoveterinary plant species were validated using The Plant List database (http://www.theplantlist.org/).

\section{Data analysis}

Descriptive statistics were used to summarize demographic characteristics of respondents and frequencies of use of ethnoveterinary plants. Summary tables were constructed to report ethnoveterinary plant species with fidelity levels, frequency indices, informant consensus factors, and other parameters based on Amorim et al., [24]. To test how the indigenous knowledge on ethnoveterinary plants vary between respondent's tribes, gender, location, and system of livestock keeping practiced by respondents we used $\chi^{2}$ test in $\mathrm{R}$ software version 3.4.4 [25]. Additionally, three quantitative indices, namely fidelity level, frequency index, and the informant consensus factor, were determined according to Amorim et al.[24].

\section{Fidelity Level}

Fidelity level is estimated as a proportion of the healing potential of each plant species reported to treat a particular livestock ailment [26,27]. We calculated the fidelity level for the most useful ethnoveterinary plants either cited more than ten times, or if they are used to treat more than one identified livestock ailment. Calculation of fidelity level was done according to Tumoro \& Maryo [27] as shown in equation (i). A high value of fidelity level shows high use frequency by the informants in treating a particular livestock ailment and vice-versa. We presented the fidelity level of only 15 common ethnoveterinary plant species. 
Where;

$\mathrm{FL}=$ Fidelity Level

$\mathrm{Np}=$ Number of informants claimed the use of a plant species in treating a particular ailment

$\mathrm{Nu}=$ Number of informants that use the plants to treat a given livestock ailment.

\section{Frequency Index}

To compare the relative importance of each ethnoveterinary plant reported, we calculated the frequency index according to Chinsembu et al. [9] as shown in equation (ii). In this case, a frequency index is high when many informants cited a particular plant and low when there are few reports about that particular ethnoveterinary plant species [9].

$\mathrm{FI}=\mathrm{FC} / \mathrm{N}$ X 100

Where;

$\mathrm{FI}=$ Frequency index

$\mathrm{FC}=$ Number of informants who cited the use of a particular ethnoveterinary plant

$\mathrm{N}=$ Total number of informants interviewed in the study area

\section{Informant Consensus factor}

We also calculated the informant consensus factor to determine the level of the agreement of information provided by different informants regarding the use of plants in treating a specific livestock ailment category. The informant consensus factor was calculated according to Uddin \& 
Hassan [28] as shown in equation (iii). Before calculating the ICF, the reported ailments were grouped into eight categories and plants used in the treatment of each ailment category were identified. Usually, ICF ranges from 0-1, whereby high ICF (close to 1.0) shows that there is a distinct group of species used by a large proportion of informants to treat a particular ailment category. A low ICF value (close to zero) indicates that informants disagree over which plant species to use in treating a particular ailment category [6]. To calculate the ICF, the cited species were grouped according to ailments categories they are used to treat i.e. Gastrointestinal diseases; dermatological and related problems; brain and nervous system; gynecological, andrological and urogenital; parasitic diseases; jaundice; Newcastle and respiratory diseases; and miscellaneous ailments. Newcastle and respiratory diseases were grouped together because Newcastle in poultry starts as an acute respiratory disease. Miscellaneous category included health complications to livestock that were not well defined by the interviewees such as general body weakness, fever and problems believed to have been resulted from evil spirits [24].

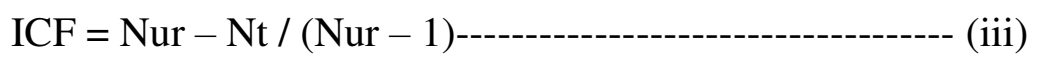

Where;

$\mathrm{ICF}=$ Informant consensus factor

Nur $=$ Number of use reports from informants for a particular ailment category

$\mathrm{Nt}=$ Number of plant species that are used for an ailment of a particular category for all informants. 


\section{Results}

\section{Demographic characteristics}

Respondents comprised of $52.2 \%(n=84)$ males and $47.8 \%(n=77)$ females. It was found that $80.1 \%(n=129)$ of respondents had formal education and $19.9 \%(n=32)$ had no formal education. Also, $47.8 \%(n=77)$ of livestock keepers do practice zero grazing, $12.4 \%$ nomadic pastoralism $(n$ $=20)$, and $39.8 \%(n=64)$ semi-sedentary pastoralism. About $31.7 \%(n=51)$ of respondents were Chagga, 22.4\% $(\mathrm{n}=36)$ Meru, 12.4\% $(\mathrm{n}=20)$ Maasai, 11.8\% $(\mathrm{n}=19)$ Pare, and $21.7 \%(\mathrm{n}=35)$ were combination of tribes which were represented by a few respondents.

\section{Ethnoveterinary knowledge}

Results showed that knowledge associated with ethnoveterinary plants was significantly higher to males than females $\left(\chi^{2}=9.1049, p<0.05\right)$, suggesting that men are more knowledgeable than women. Further results show that knowledge of respondents on ethnoveterinary plants for preventing or treating livestock ailments was found to be associated with the ethnic group of the respondent $\left(\chi^{2}=15.621, p<0.05\right)$, and animal husbandry practiced by respondents $\left(\chi^{2}=7.6999, p\right.$ $<0.05)$.

\section{Use of ethnoveterinary plants in the treating livestock ailments}

\section{Reported plants with veterinary uses}

A total of 54 plant species were reported to be used by respondents for preparing phytotherapy for preventing or treating various ailments in livestock the study area. The majority of plant species with ethnoveterinary uses were trees (46\%) followed by shrubs (24\%) and herbs (13\%) (Figure 2). We also found ethnoveterinary plants belonging to 51 genera and 35 families. Fabaceae was the 
most diverse family being represented 13\% (7) species, closely followed by Euphorbiaceae and Asteraceae families $7.4 \%$ (4) species in each. The remaining 32 families were represented by one to a maximum of two species (Figure 3).

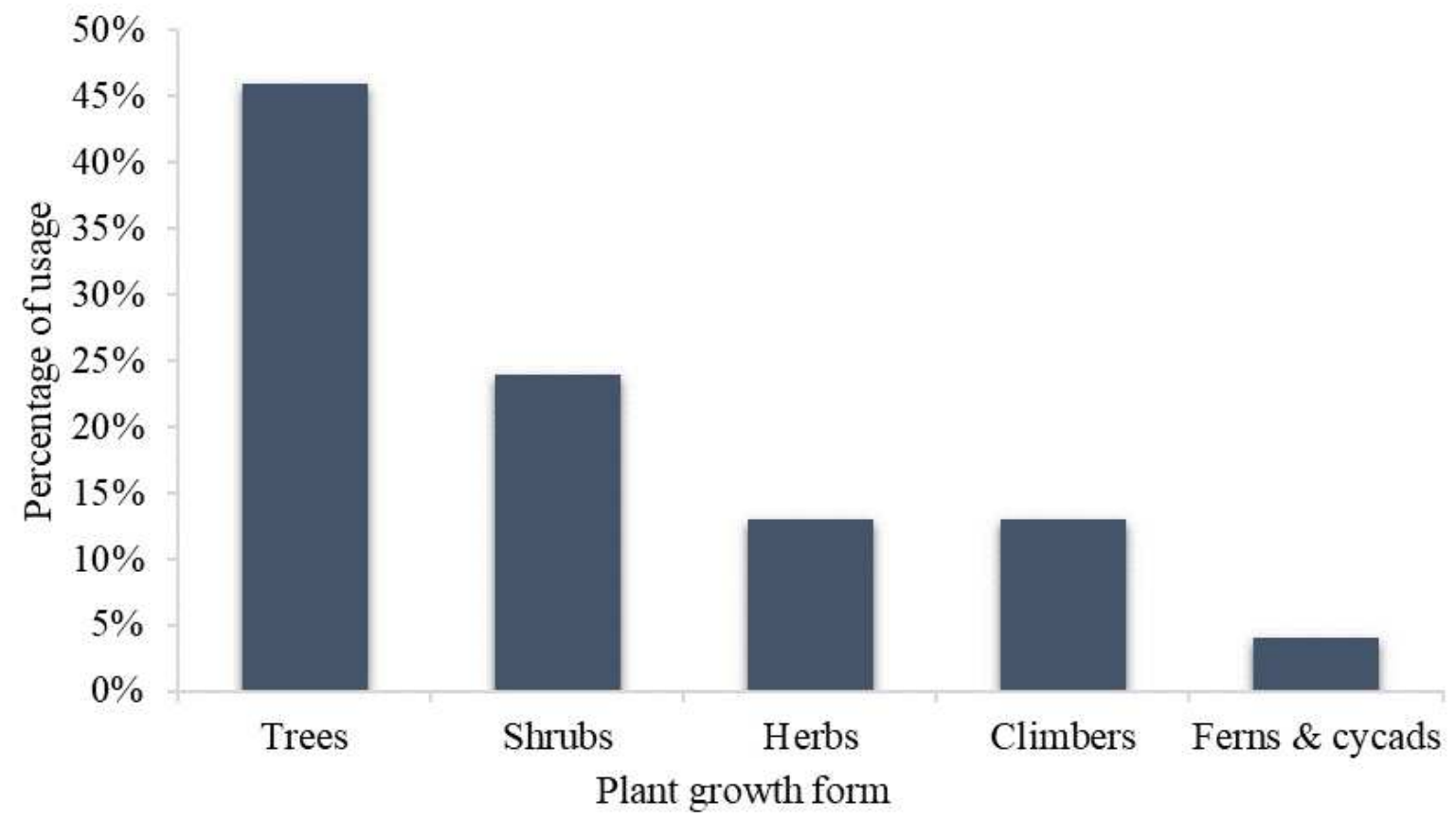

Figure 2. Distribution of plants into different life forms. Bars show the percentage of identified ethnoveterinary plants in each growth habit category. 


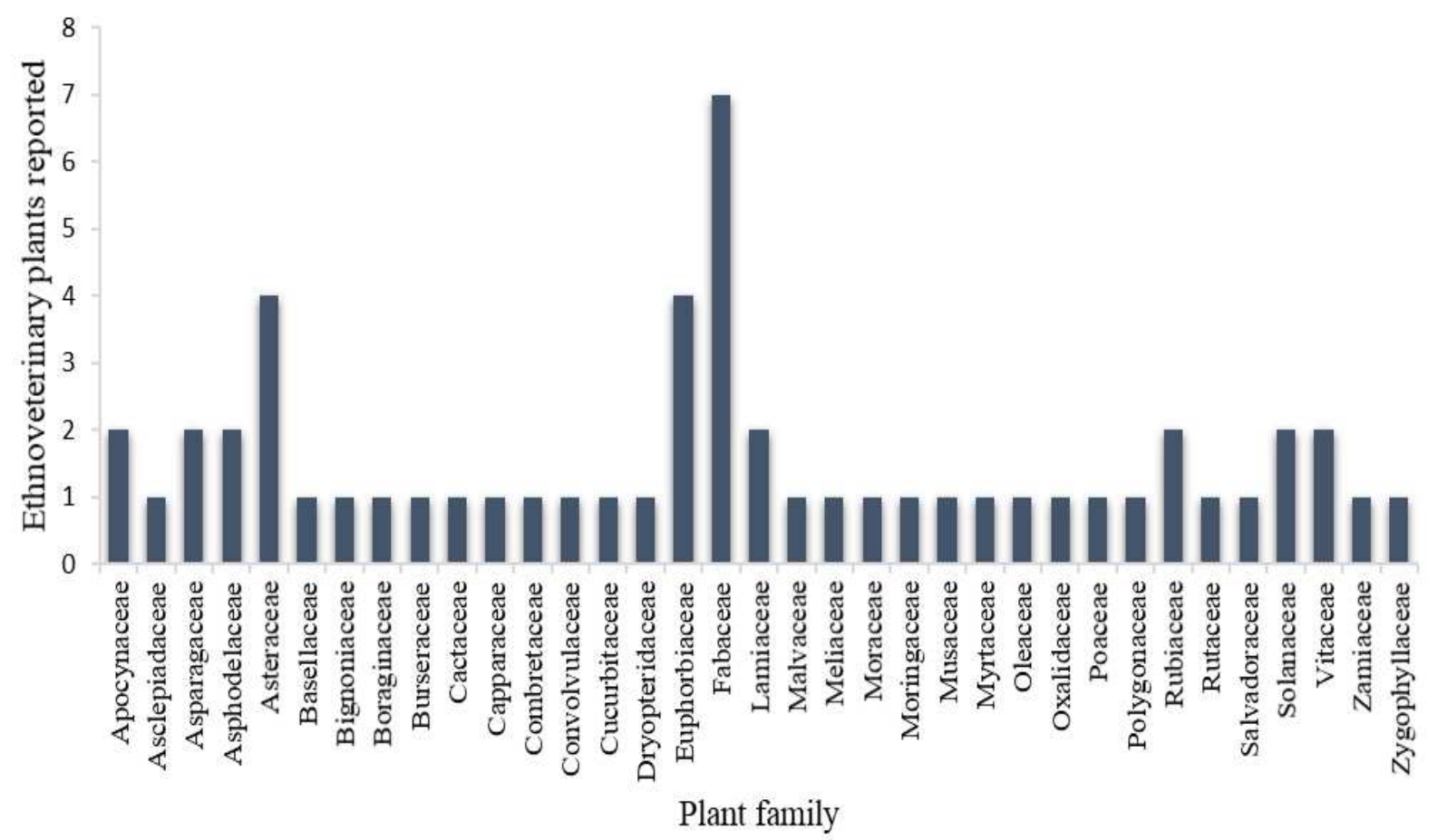

Figure 3. Distribution of plants in different families. Bars indicate family and number of ethnoveterinary plants reported. 


\section{Plant parts used, means for preparation and dosage administration}

Results indicate that plant remedies for livestock ailments are prepared from the leaves (59\%), barks $(20 \%)$, fruits $(8 \%)$, roots $(7 \%)$, sap (3\%) and whole plant $(3 \%)$ (Figure 4$)$. Conventional methods used to prepare traditional medication for treating or preventing livestock ailments included infusions (29\%), decoctions (17\%), macerated leaves (15\%), grinding of barks (8\%) and burning some plant parts to create smoke (5\%) (Figure 5). The remaining proportion included medications taken directly by livestock as part of the fodder (26\%) (Figure 5). Of all preparations, only $22.1 \%$ were reported as a mixture of plant materials from one or more species with additives such as milk or salts, while the remaining $77.9 \%$ contained materials from a single plant species alone. We also found that $77 \%$ of the preparations were administered orally while others were reported to be applied externally, through steam inhalation, aroma sniffing, and smoke bath (Table 1 and Figure 6).

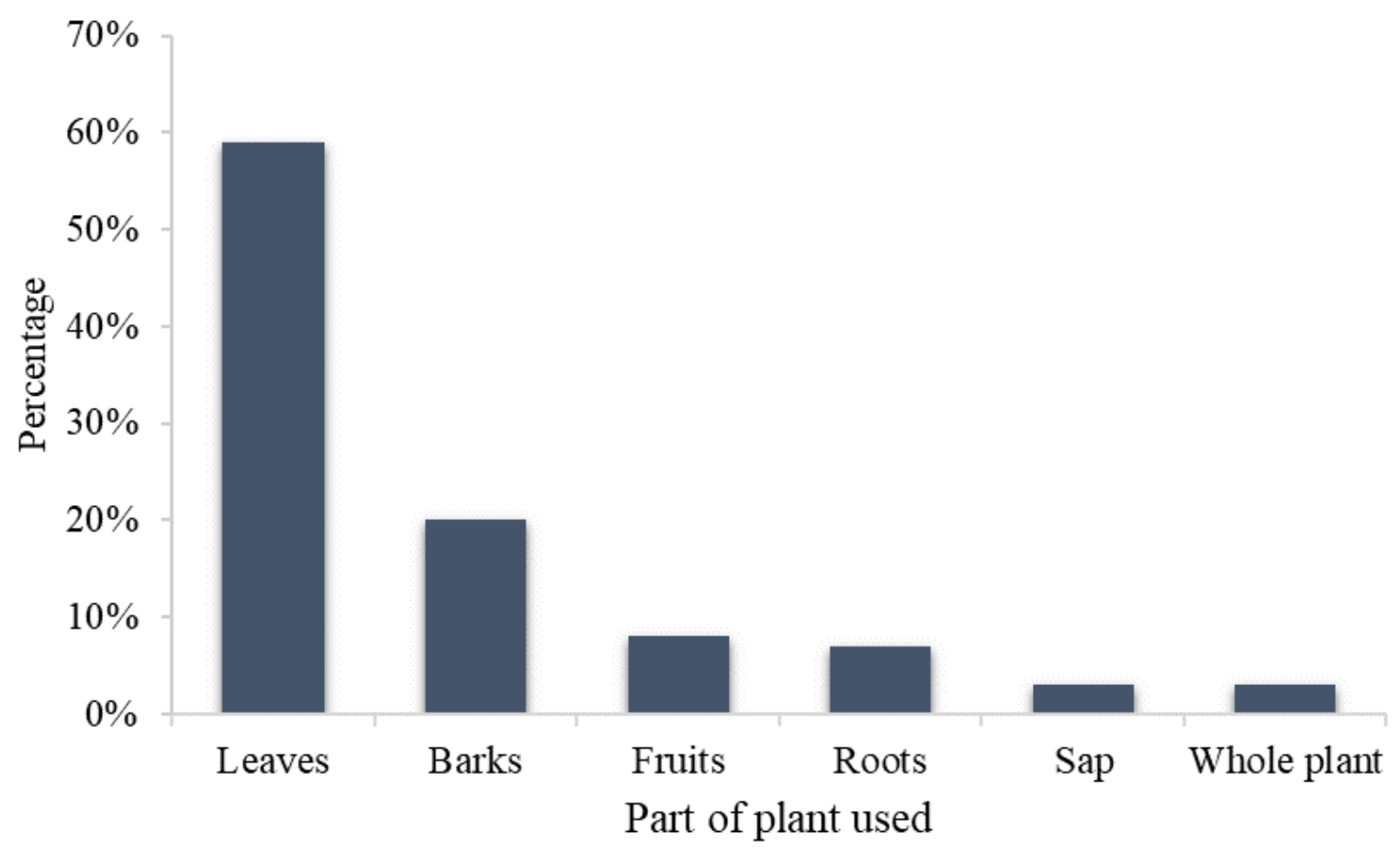


Figure 4. Parts of plant used for preparing a traditional medicine and percentage of usage in treating or preventing livestock ailments.

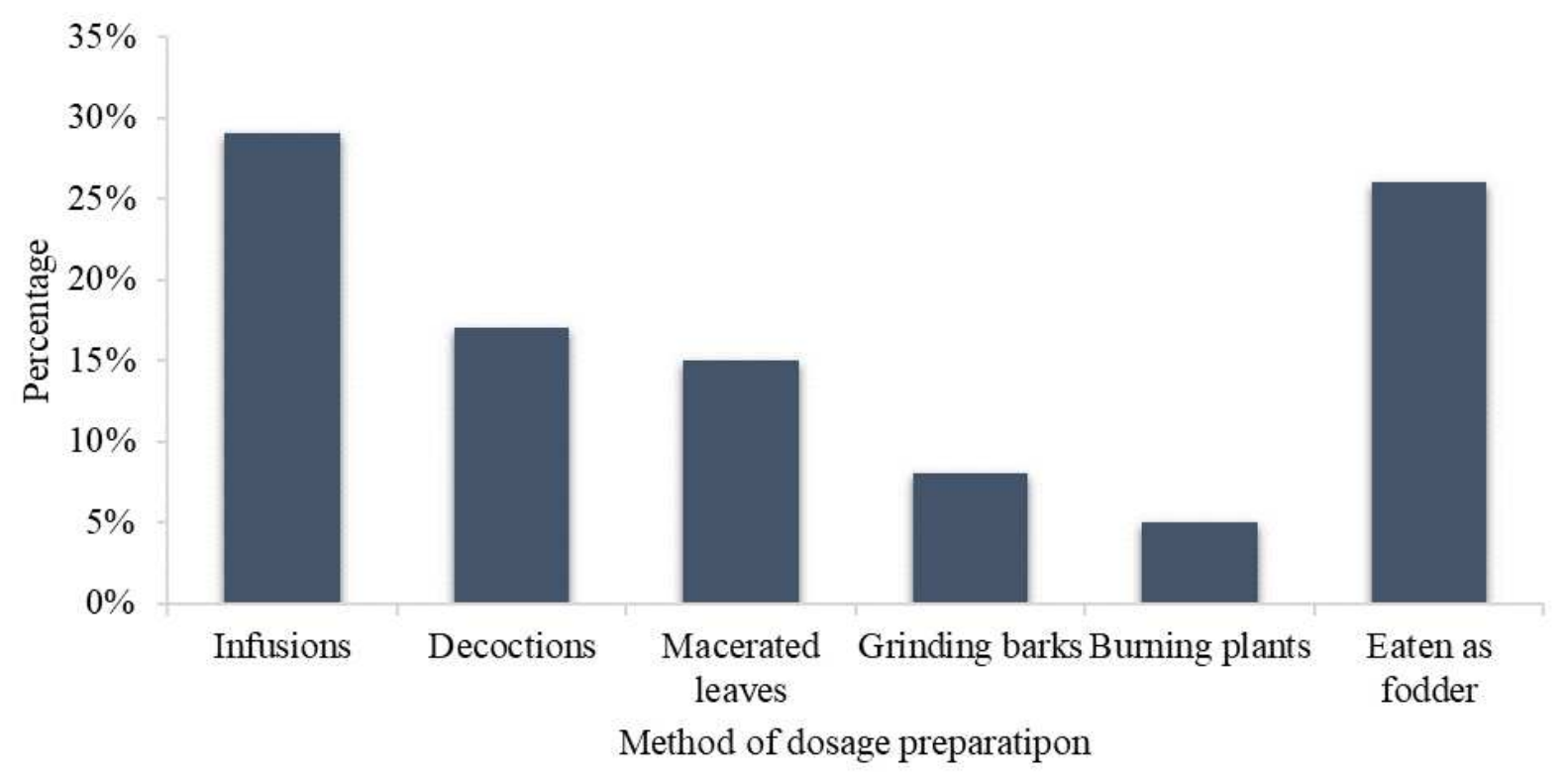

Figure 5. Methods of preparing traditional phytotherapy, and percentage of respondent's citations by livestock keepers. 


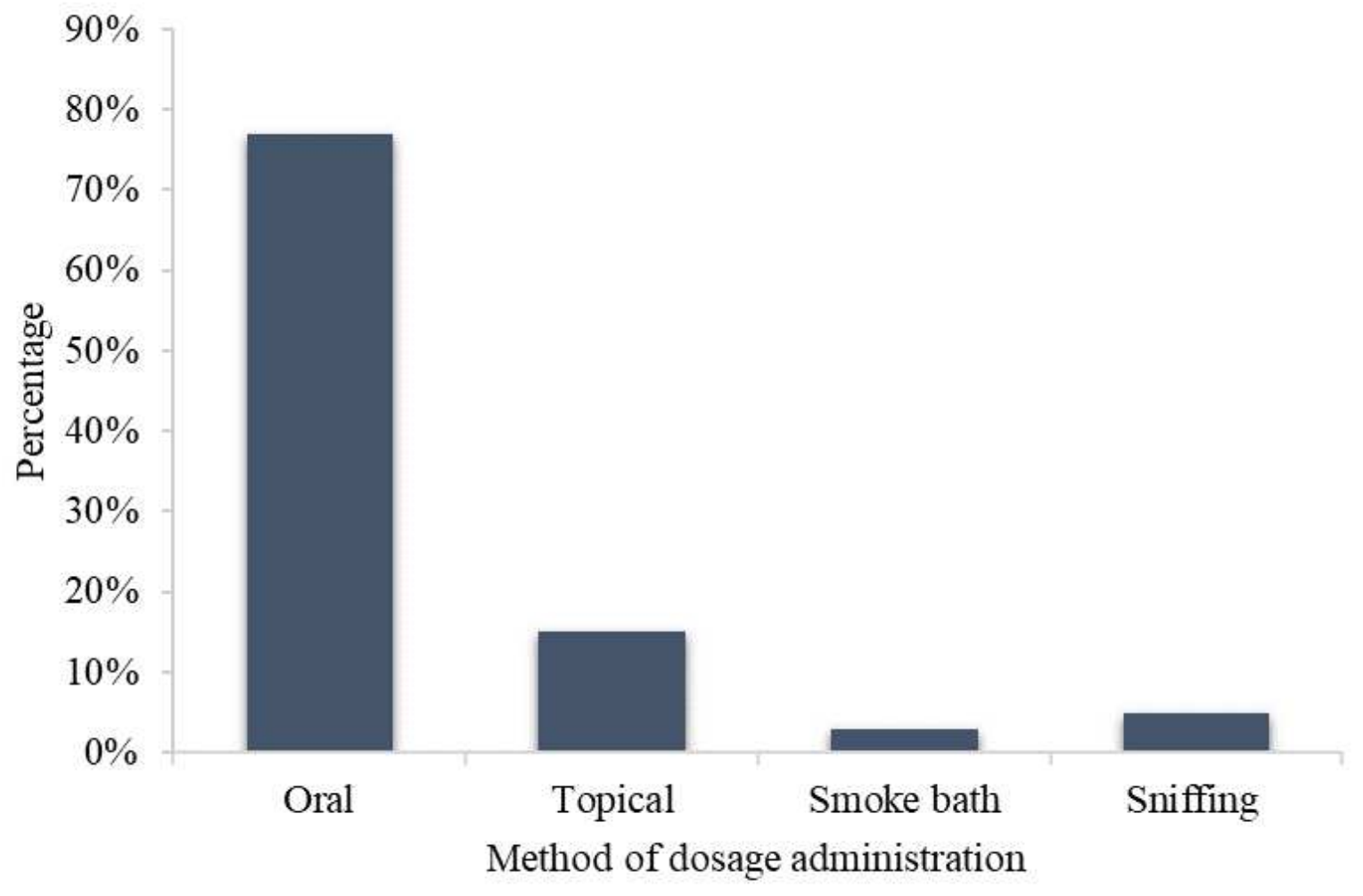

Figure 6. Methods of dosage administration. Bars show the percentage of respondent's citations for a particular method of administering traditional medications.

Fidelity level (FI) and ethnomedicinal practices in treating livestock ailments

We found that Aloe vera (L.) Burm and Aloe volkensii Engl. have the highest FI (40.45) each (Table 1). A. vera and A. volkensii were frequently reported to treat Newcastle in poultry, and antidiarrhoea in cattle, respectively. Also, we report a narrative of all ethnoveterinary plants reported during this study, families, local names, part used, animal treated, ailment treated, dosage preparation and administration (Table 1) 
Table 1: Ethnoveterinary plants used by tribal people in Siha, Hai, Moshi and Meru districts in the Northern Tanzania. The table contains the list of medicinal plant species used, botanical name and family, their local names, frequency index (FI), part used, type of livestock and ailment treated, methods of dosage preparation and administration.

\begin{tabular}{|c|c|c|c|c|c|c|}
\hline $\begin{array}{l}\text { Family, Species, } \\
\text { (habit) }\end{array}$ & $\begin{array}{l}\text { Vernacular name } \\
\text { (Tribe mentioned } \\
\text { the use) }\end{array}$ & $\begin{array}{l}\text { Frequency } \\
\text { Index }\end{array}$ & $\begin{array}{l}\text { Plant } \\
\text { part } \\
\text { used }\end{array}$ & $\begin{array}{l}\text { Animal } \\
\text { treated }\end{array}$ & $\begin{array}{l}\text { Ailment } \\
\text { treated/Medicinal } \\
\text { use }\end{array}$ & $\begin{array}{l}\text { Dosage preparation } \\
\text { and administration }\end{array}$ \\
\hline \multicolumn{7}{|l|}{ APOCYNACEAE } \\
\hline $\begin{array}{l}\text { Rauvolfia caffra Sond. } \\
\text { (Tree) }\end{array}$ & $\begin{array}{l}\text { Msesewe (Chagga, } \\
\text { Meru) }\end{array}$ & 13.66 & B & $\mathrm{Gt}$ & $\begin{array}{l}\text { Endoparasites, } \\
\text { jaundice }\end{array}$ & $\begin{array}{l}\text { Ground barks are mix } \\
\text { with salt and } \\
\text { administered orally }\end{array}$ \\
\hline & & & $\mathrm{L}$ & $\mathrm{Ctl}$ & East Coast fever & Infusion of macerated \\
\hline & & & & & & $\begin{array}{l}\text { leaves mixed with } \\
\text { leaves of } A \text {. indica, } \\
\text { administered orally. }\end{array}$ \\
\hline & & & $S$ & $\begin{array}{l}\text { Ctl, Gt, } \\
\text { Shp }\end{array}$ & External wounds & $\begin{array}{l}\text { Sap applied topically } \\
\text { on wounds }\end{array}$ \\
\hline
\end{tabular}




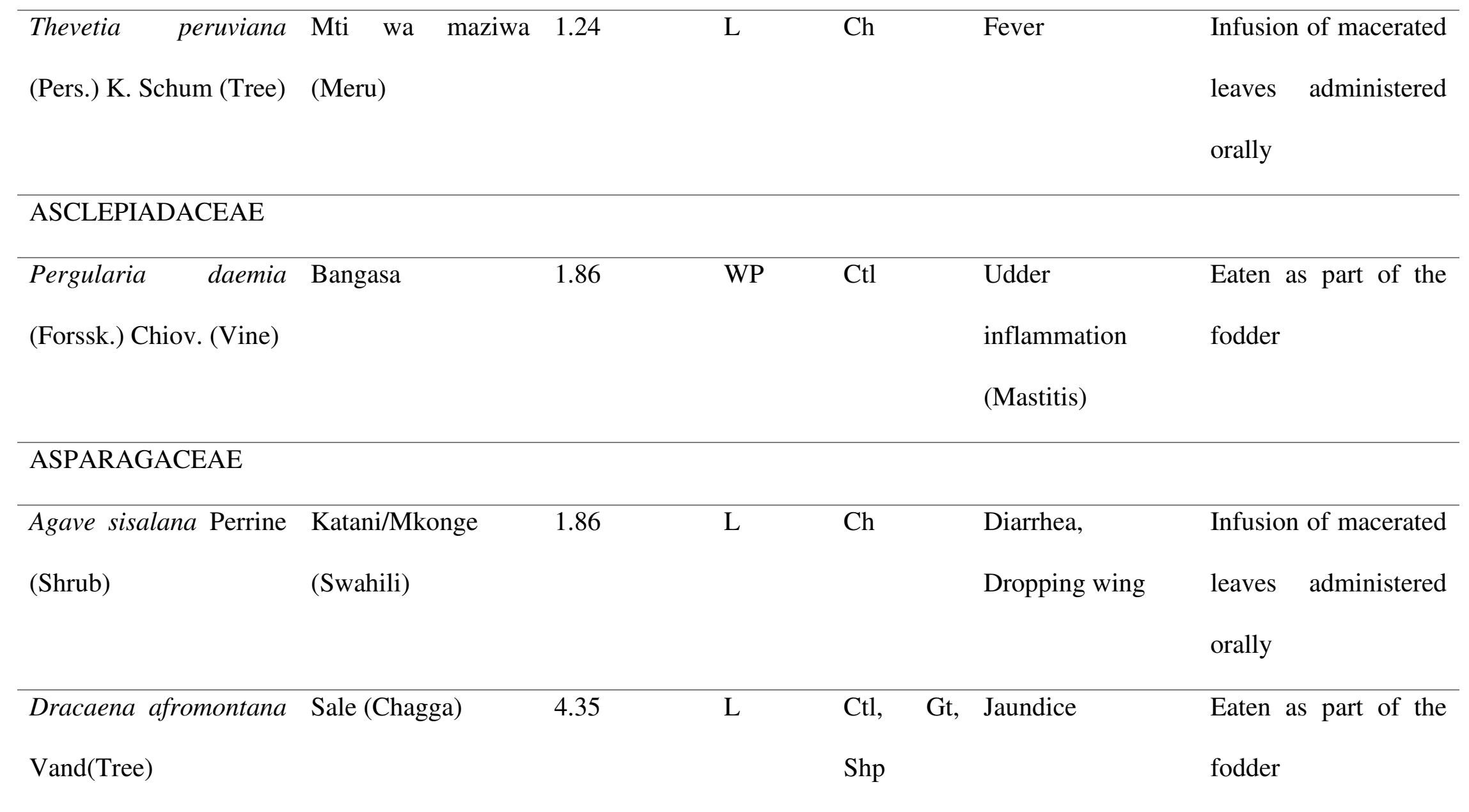

\section{ASPHODELACEAE}

Ikori (Rangi) 


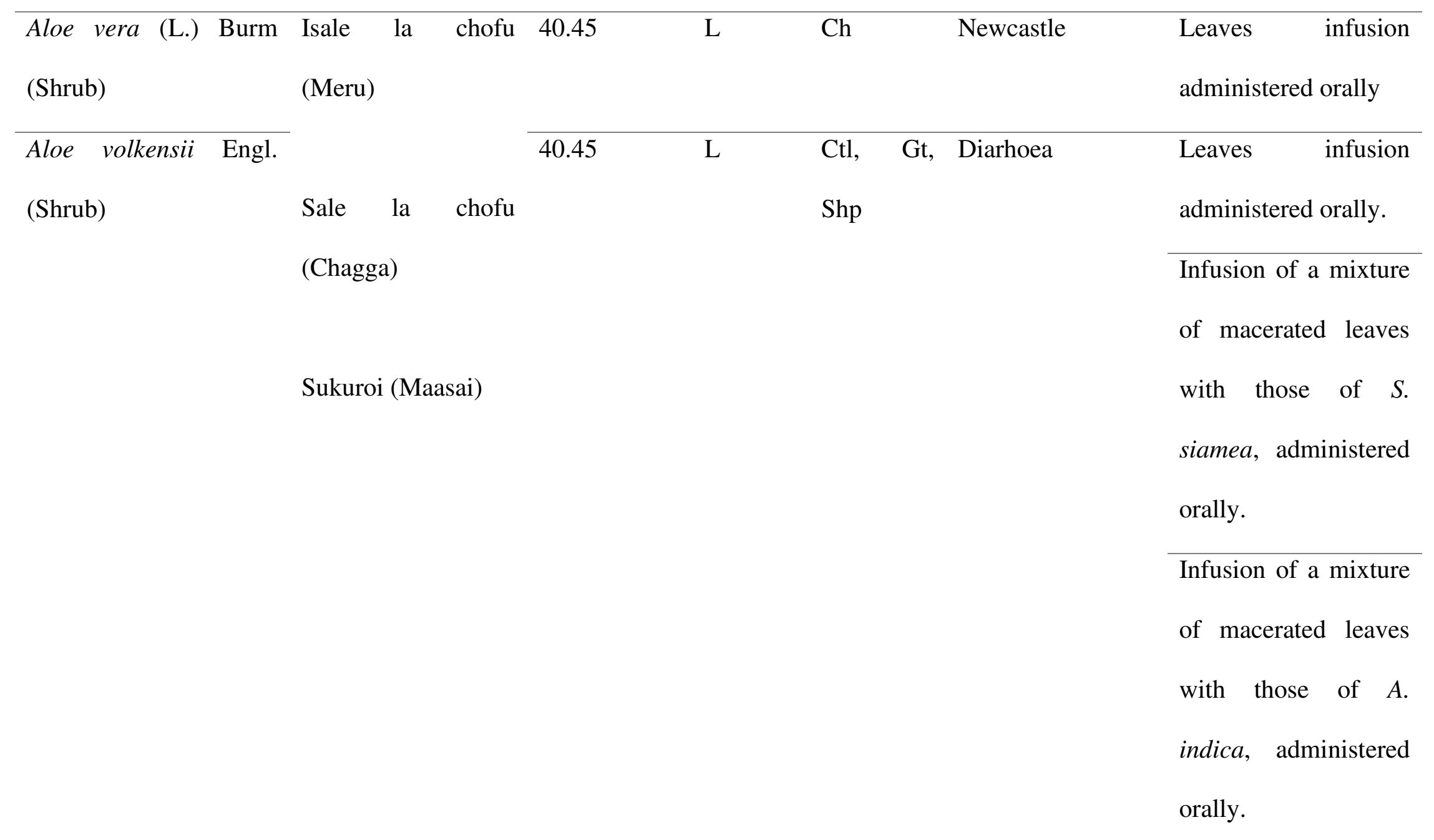




\begin{tabular}{|c|c|c|c|c|c|c|}
\hline $\begin{array}{l}\text { Ageratum conyzoides } \mathrm{L} . \\
(\text { Herb })\end{array}$ & Ifuna (Chagga) & 5.59 & $\mathrm{~L}$ & $\mathrm{Ctl}$ & Loss of appetite & Eaten as part fodder \\
\hline Bidens pilosa L. (Herb) & Kirembe (Chagga) & 4.35 & $\mathrm{~L}$ & $\mathrm{Ch}$ & Body weakness & $\begin{array}{l}\text { Infusion of macerated } \\
\text { leaves administered } \\
\text { orally using a spoon }\end{array}$ \\
\hline $\begin{array}{l}\text { Tithonia diversifolia } \\
\text { (Hemsl.) A. Gray } \\
\text { (shrub) }\end{array}$ & $\begin{array}{l}\text { Ikingili (Chagga, } \\
\text { Meru) }\end{array}$ & 12.42 & $\mathrm{~L}$ & $\mathrm{Ch}, \mathrm{Ctl}$ & Jaundice & $\begin{array}{l}\text { Infusion of macerated } \\
\text { leaves administered } \\
\text { orally, or leaves eaten } \\
\text { in fodder }\end{array}$ \\
\hline & & & & & Endoparasites & $\begin{array}{l}\text { Leaves decoction } \\
\text { administered orally }\end{array}$ \\
\hline $\begin{array}{l}\text { Gymnanthemum } \\
\text { auriculiferum (Hiern) } \\
\text { Isawumi (Shrub) }\end{array}$ & Iringiringi (Chagga) & 1.86 & $\mathrm{~L}$ & $\mathrm{Ctl}$ and $\mathrm{Gt}$ & Bloat, constipation & $\begin{array}{l}\text { Eaten as part of fodder } \\
\text { and when in extreme } \\
\text { condition macerated } \\
\text { leaves are } \\
\text { administered orally }\end{array}$ \\
\hline
\end{tabular}




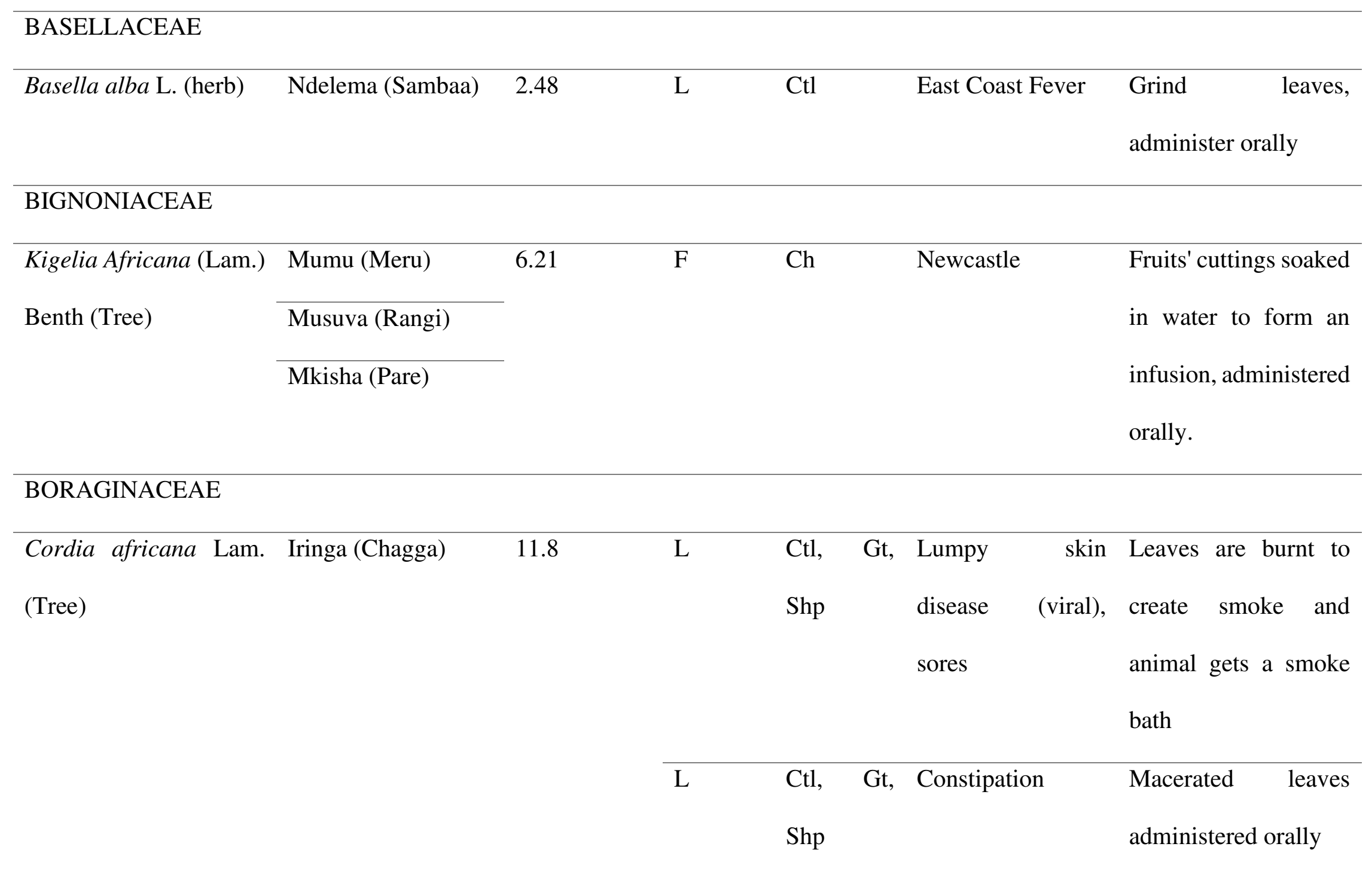




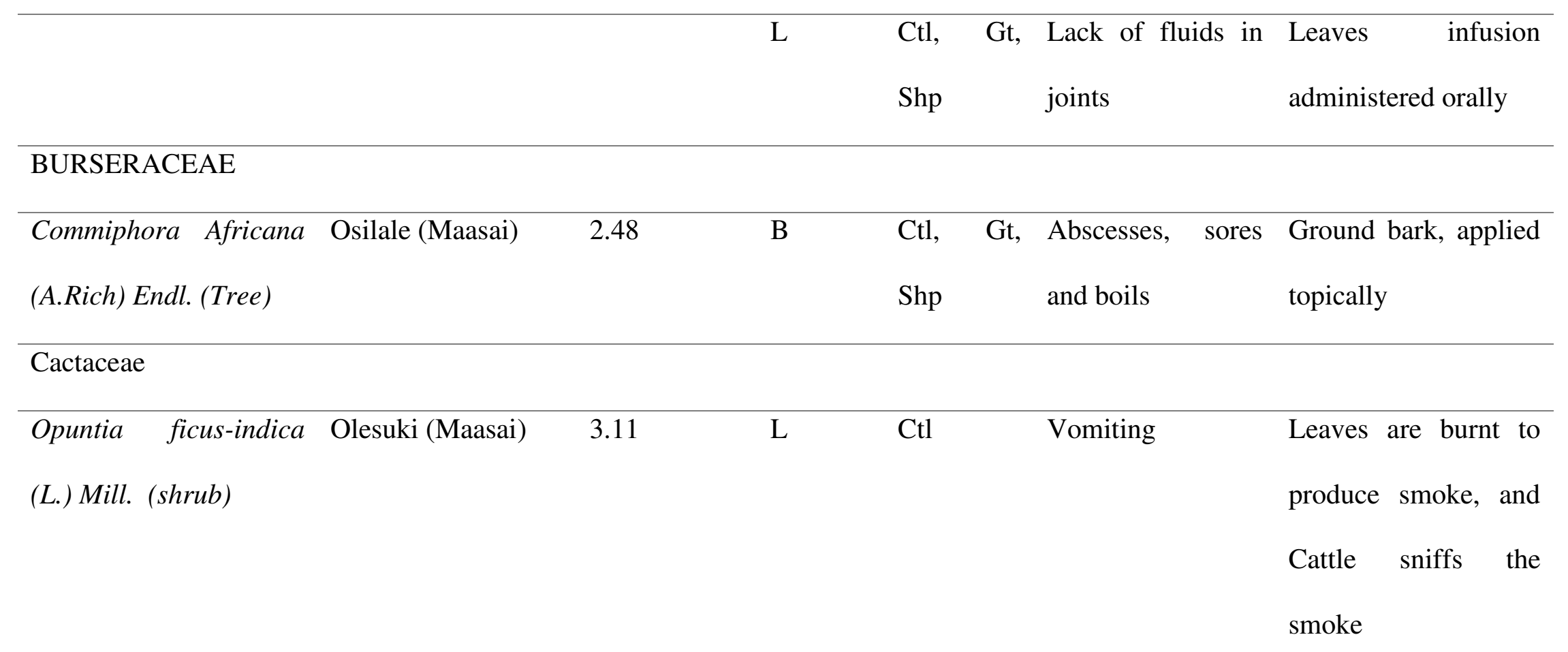

\section{CAPPARACEAE}

\begin{tabular}{|c|c|c|c|c|c|c|}
\hline triphylla & Engamoloki & 2.48 & $\mathrm{R}$ & Ctl, & Silent and delaying & decoction \\
\hline A.Rich. (Shrub) & (Maasai) & & & Shp & heat & administered orally \\
\hline
\end{tabular}

Combretaceae 


\begin{tabular}{|c|c|c|c|c|c|c|}
\hline $\begin{array}{l}\text { Terminalia Brownii } \\
\text { Fres. (Tree) }\end{array}$ & Olbukoi & 1.86 & $\mathrm{~B}$ & Shp & Diarhhea & $\begin{array}{l}\text { Ground bark mixed } \\
\text { with milk, administer } \\
\text { orally }\end{array}$ \\
\hline CONVOLVULACEAE & & & & & & \\
\hline $\begin{array}{l}\text { Cuscuta kilimanjari } \\
\text { Oliv. (Climber) }\end{array}$ & $\begin{array}{l}\text { Kibora warile } \\
\text { (Meru) } \\
\text { Kyolokanarue } \\
\text { (Chagga) }\end{array}$ & 3.11 & WP & $\mathrm{Ctl}$ & $\begin{array}{l}\text { Silent and delaying } \\
\text { heat }\end{array}$ & $\begin{array}{l}\text { Macerated plant } \\
\text { mixed in maize bran }\end{array}$ \\
\hline CUCURBITACEAE & & & & & & \\
\hline $\begin{array}{l}\text { Zehneria scabra Sond. } \\
\text { (Vine) }\end{array}$ & Ndafi & 1.24 & $\mathrm{~L}$ & $\mathrm{Ctl}$ & $\begin{array}{l}\text { Silent and delaying } \\
\text { heat }\end{array}$ & $\begin{array}{l}\text { Macerated leaves } \\
\text { applied topically on } \\
\text { the female genitals }\end{array}$ \\
\hline DRYOPTERIDACEAE & & & & & & \\
\hline $\begin{array}{l}\text { Dryopteris } \\
\text { campyloptera (Kunze) } \\
\text { Clarkson (Fern) }\end{array}$ & $\begin{array}{l}\text { Iwawangiwa } \\
\text { (Chagga) }\end{array}$ & 0.62 & $\mathrm{~L}$ & $\mathrm{Ctl}$ & $\begin{array}{l}\text { Silent and delaying } \\
\text { heat }\end{array}$ & $\begin{array}{l}\text { Eaten as part of the } \\
\text { fodder }\end{array}$ \\
\hline
\end{tabular}




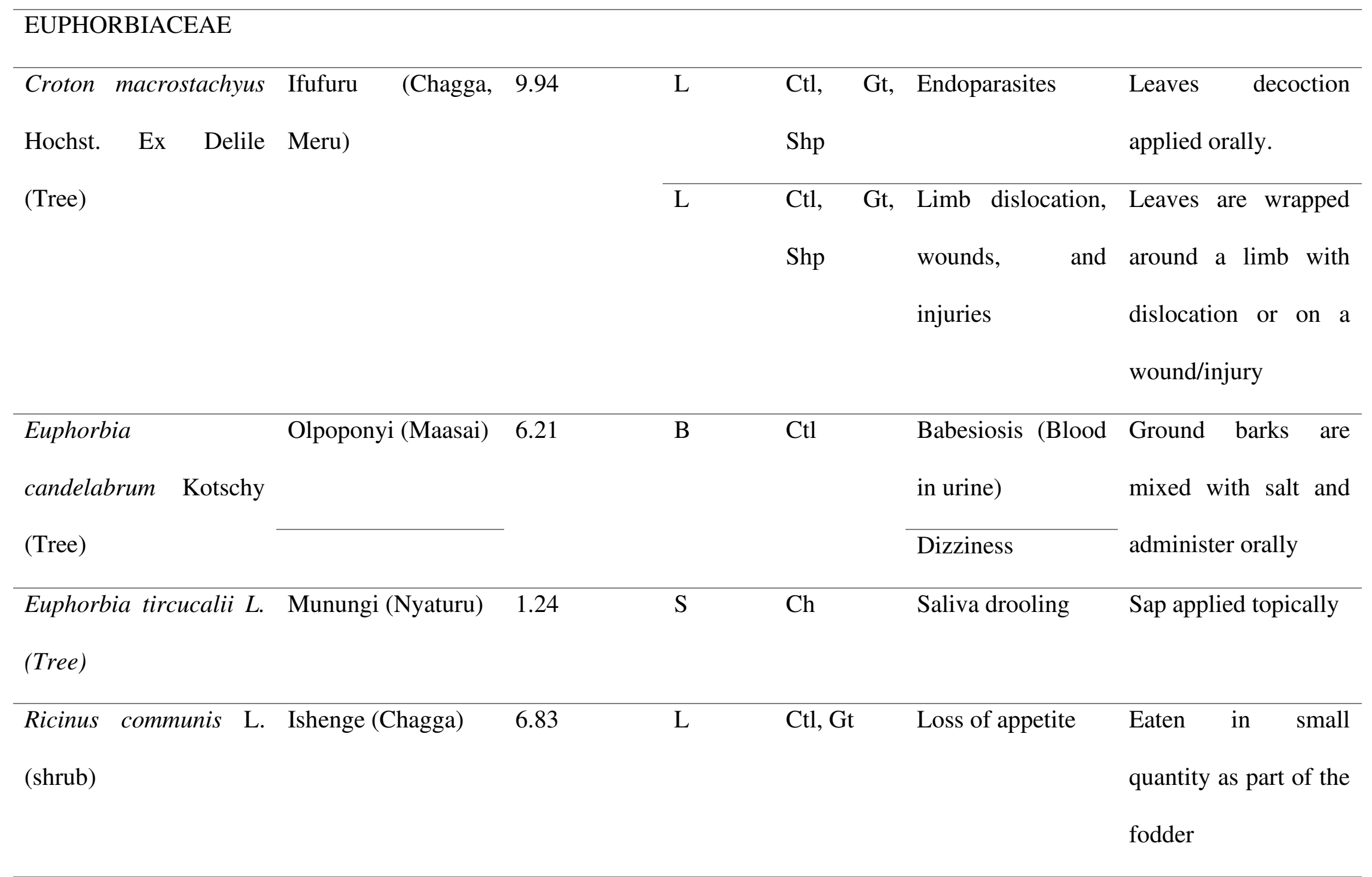




\begin{tabular}{|c|c|c|c|c|c|}
\hline & & & $\begin{array}{l}\text { Ctl, Gt, } \\
\text { Shp }\end{array}$ & Limb dislocation & $\begin{array}{l}\text { Boiled leaves are } \\
\text { wrapped around a } \\
\text { limb with dislocation }\end{array}$ \\
\hline FABACEAE & & & & & \\
\hline $\begin{array}{l}\text { Albizia amara (Roxb.) Mtanga (Pare) } \\
\text { Boiv (Tree) }\end{array}$ & 1.24 & $\mathrm{~B}$ & $\mathrm{Ctl}$ & Evil eye & $\begin{array}{l}\text { Burnt to create smoke } \\
\text { and cattle takes a } \\
\text { smoke bath }\end{array}$ \\
\hline $\begin{array}{l}\text { Erythrina abyssinica Ididi (Chagga) } \\
\text { Lam. (Tree) }\end{array}$ & 2.48 & $\mathrm{~B}$ & $\begin{array}{l}\text { Ctl, Gt, } \\
\text { Shp }\end{array}$ & Endoparasites & $\begin{array}{l}\text { Eaten as part of the } \\
\text { fodder }\end{array}$ \\
\hline $\begin{array}{l}\text { Leucaena leucocephala Uruchwa (Chagga) } \\
\text { Lam. (Tree) }\end{array}$ & 0.62 & $\mathrm{~L}$ & $\mathrm{Ch}$ & $\begin{array}{l}\text { Jaundice, poor } \\
\text { quality eggs }\end{array}$ & $\begin{array}{l}\text { Dried leaves are } \\
\text { mixed with maize } \\
\text { bran }\end{array}$ \\
\hline $\begin{array}{lll}\text { Senna siamea } & \text { Lam. } & \text { Mjohoro } \\
\text { (Tree) } & & \\
\end{array}$ & 0.62 & $\mathrm{~L}$ & $\mathrm{Ch}$ & Newcastle & $\begin{array}{l}\text { Infusion of a mixture } \\
\text { of macerated leaves } \\
\text { with those of Aloe }\end{array}$ \\
\hline
\end{tabular}


species, administered

orally

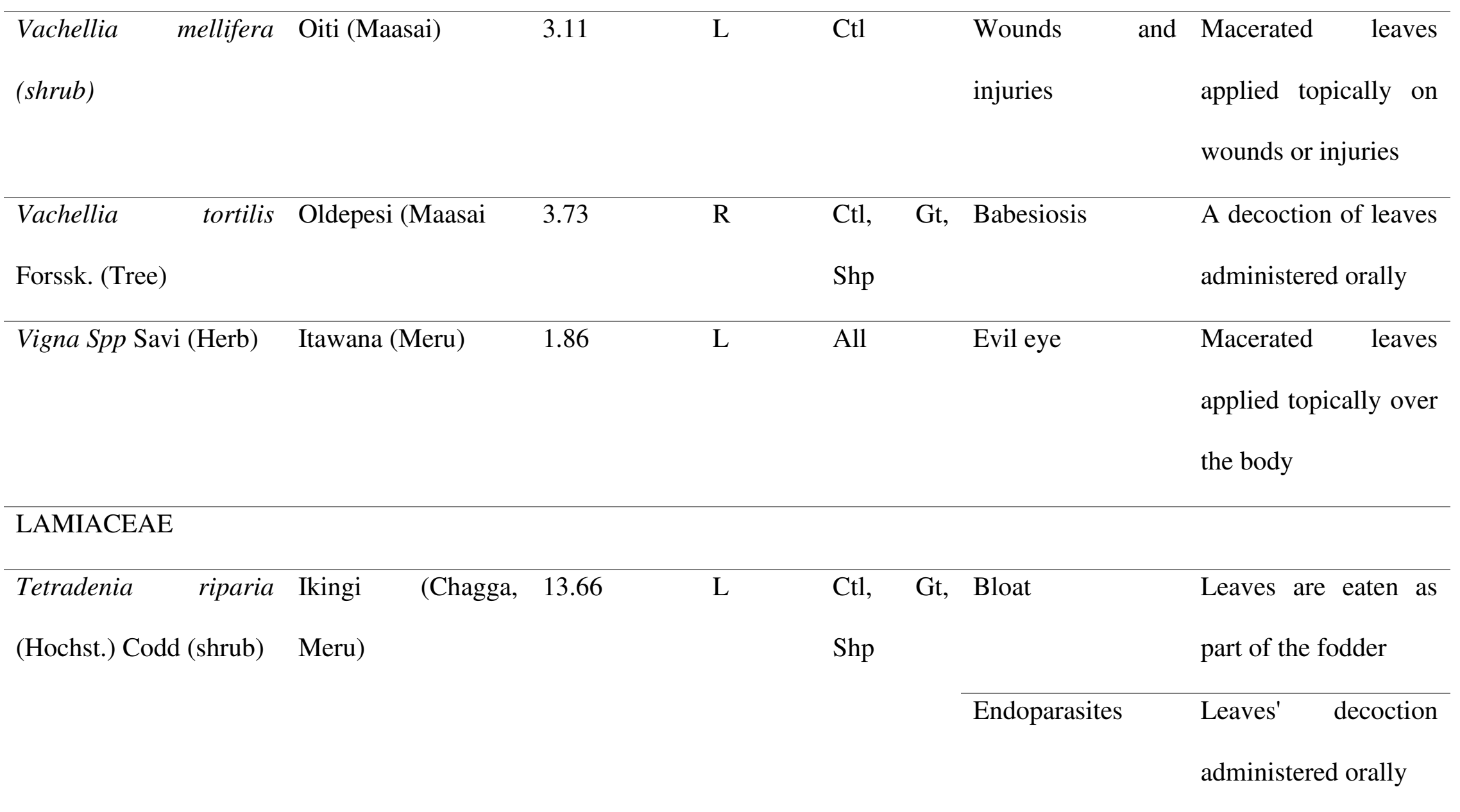




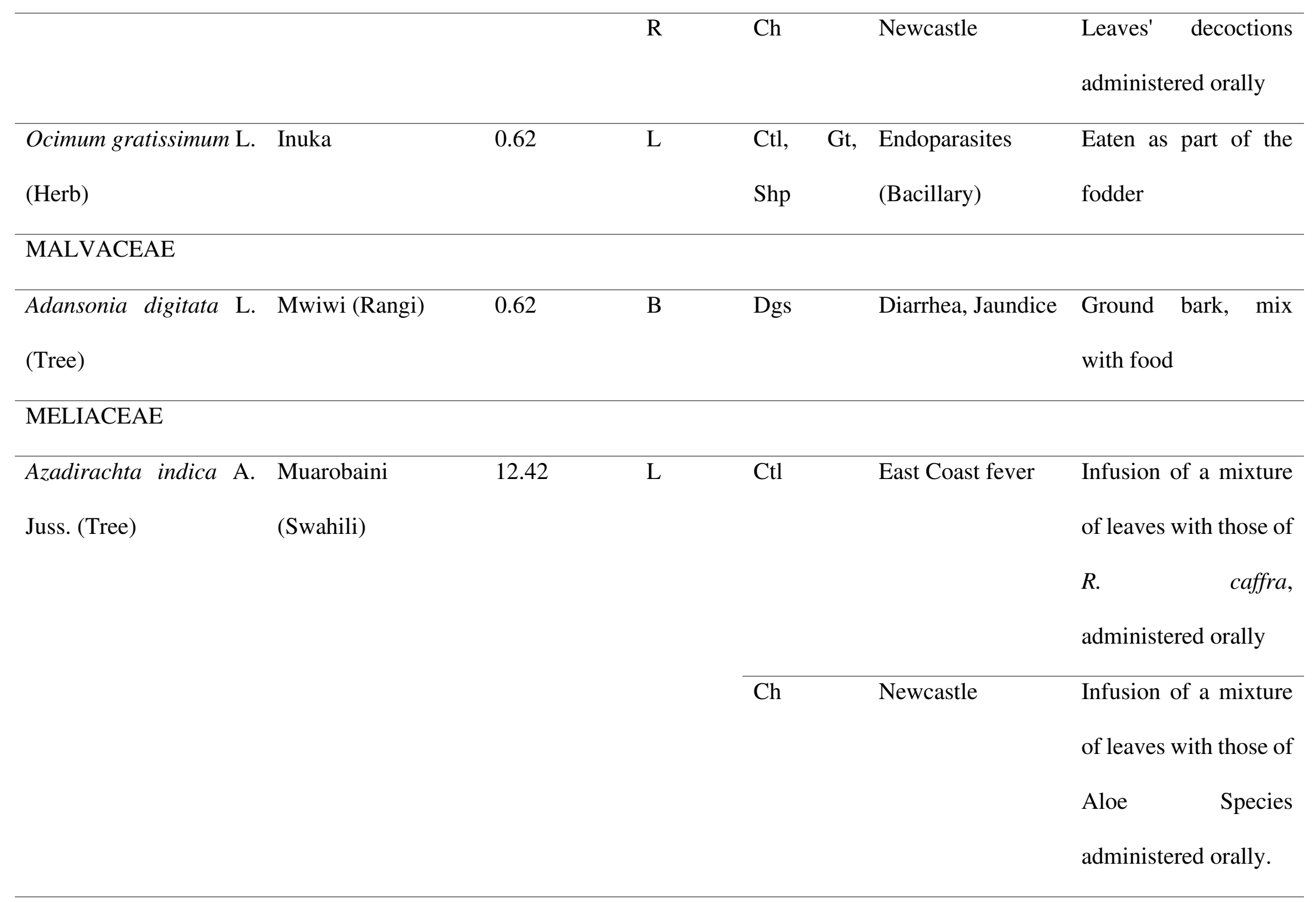




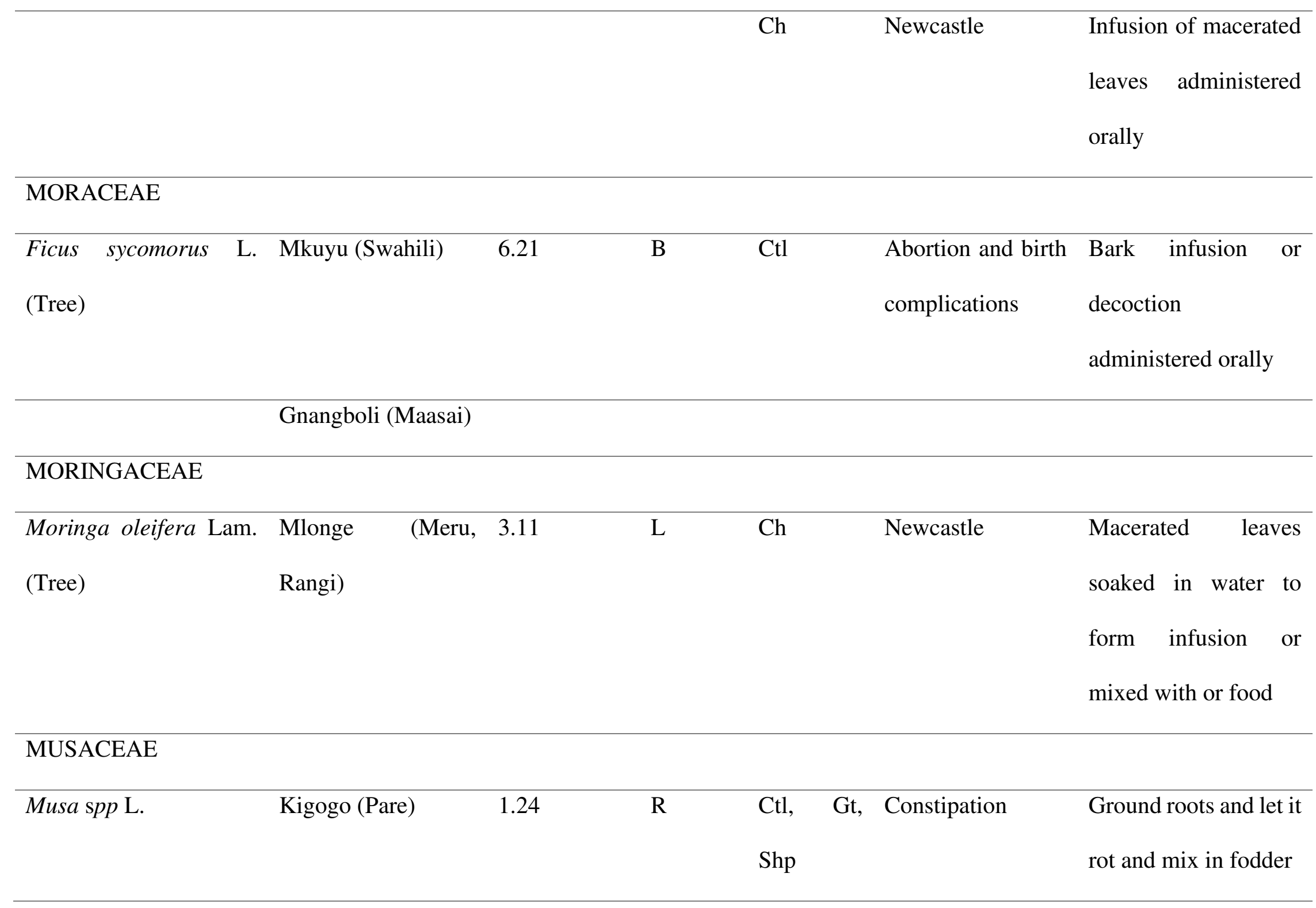




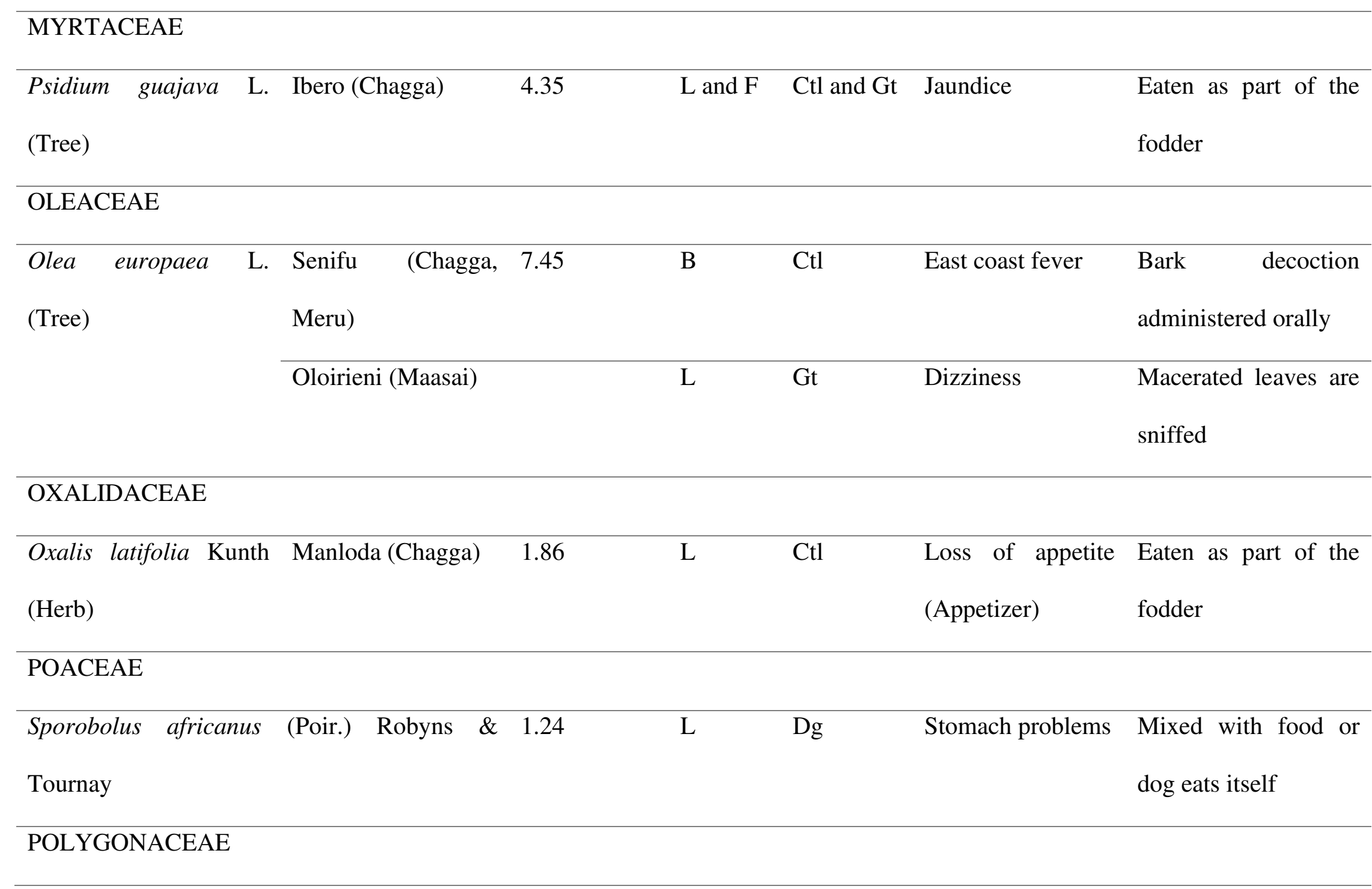




\begin{tabular}{|c|c|c|c|c|c|c|}
\hline $\begin{array}{l}\text { Rumex usambarensis } \\
\text { Dammer (Climber) }\end{array}$ & Manloda (Chagga) & 3.11 & $\mathrm{~L}$ & $\mathrm{Ctl}$ & $\begin{array}{l}\text { Loss of appetite } \\
\text { (Appetizer) }\end{array}$ & $\begin{array}{l}\text { Eaten as part of the } \\
\text { fodder }\end{array}$ \\
\hline RUBIACEAE & & & & & & \\
\hline $\begin{array}{l}\text { Cinchona officinalis L. } \\
\text { (Tree) }\end{array}$ & Sachona (Meru) & 8.7 & $\mathrm{~B}$ & $\begin{array}{l}\text { Ctl } \\
\text { Ctl, Gt, } \\
\text { Shp }\end{array}$ & $\begin{array}{l}\text { Trypanosomiasis } \\
\text { Fever }\end{array}$ & $\begin{array}{l}\text { Bark decoction } \\
\text { administered orally }\end{array}$ \\
\hline $\begin{array}{l}\text { Rubia cordifolia L. } \\
\text { (Climber) }\end{array}$ & Kitariche (Chagga) & 2.48 & $\mathrm{~F}$ & $\mathrm{Ctl}$ & Manges & Juice applied topically \\
\hline RUTACEAE & & & & & & \\
\hline $\begin{array}{l}\text { Zanthoxylum } \\
\text { chalybeum Engl. (Tree) }\end{array}$ & Oluisuki (Maasai) & 1.86 & B & $\mathrm{Ctl}$ & Vomiting & $\begin{array}{l}\text { Burnt to create smoke } \\
\text { and cattle sniffs the } \\
\text { smoke }\end{array}$ \\
\hline SALVADORACEAE & & & & & & \\
\hline $\begin{array}{l}\text { Salvadora persica L. } \\
\text { (Shrub) }\end{array}$ & Oriemiti (Maasai) & 2.48 & $\mathrm{~L}$ & $\begin{array}{l}\text { Ctl, Gt, } \\
\text { Shp }\end{array}$ & Jaundice & $\begin{array}{l}\text { Leaves decoction } \\
\text { administered orally }\end{array}$ \\
\hline
\end{tabular}

\section{SOLANACEAE}




\begin{tabular}{|c|c|c|c|c|c|c|}
\hline $\begin{array}{l}\text { Capsicum frutescens L. } \\
\text { (shrub) }\end{array}$ & $\begin{array}{l}\text { Bilibili (Chagga, } \\
\text { Meru) }\end{array}$ & 8.07 & $\mathrm{~F}$ & $\mathrm{Ch}$ & Newcastle & $\begin{array}{l}\text { Infusion of Ground } \\
\text { fruits administered } \\
\text { orally }\end{array}$ \\
\hline $\begin{array}{l}\text { Nicotiana tabacum L. } \\
\text { (Shrub) }\end{array}$ & $\begin{array}{l}\text { Mbatu (Meru, } \\
\text { Chagga) }\end{array}$ & 2.48 & $\mathrm{~L}$ & $\mathrm{Ch}$ & Mites & $\begin{array}{l}\text { Leaves are spread on } \\
\text { the floor }\end{array}$ \\
\hline \multicolumn{7}{|l|}{ VITACEAE } \\
\hline $\begin{array}{l}\text { Cissus quadrangularis } \\
\text { L. (Climber) }\end{array}$ & Indijai (Maasai) & 2.48 & $\mathrm{~L}$ & $\mathrm{Ctl}$ & Stomach problems & $\begin{array}{l}\text { Leaves decoction } \\
\text { administered orally }\end{array}$ \\
\hline $\begin{array}{l}\text { Cyphostemma } \\
\text { kilimandscharica Gilg } \\
\text { (Climber) }\end{array}$ & Lodwa (Maasai) & 1.86 & $\mathrm{~F}$ & $\mathrm{Gt}$ & Colds, fever & $\begin{array}{l}\text { Ground fruits are } \\
\text { mixed with milk and } \\
\text { administered orally }\end{array}$ \\
\hline \multicolumn{7}{|l|}{ ZAMIACEAE } \\
\hline $\begin{array}{l}\text { Encephalartos } \\
\text { whitelockii (Cycad) }\end{array}$ & Imanko (Chagga) & 1.24 & $\mathrm{~L}$ & $\mathrm{Gt}$ & Diarrhea & $\begin{array}{l}\text { Eaten as part of the } \\
\text { fodder }\end{array}$ \\
\hline
\end{tabular}

ZYGOPHYLLACEAE 


\begin{tabular}{lllllll}
\hline Balanites aegyptiaca & Olng'oswa (Maasai) & 1.86 & B & Ctl & Placental retention & Decoction \\
(L.) Delile (Tree) & & & & administered orally
\end{tabular}

L—leaves, B—bark, R—root, S—sap, F—fruit, WP_Whole plant. Ctl_Cattle, Gt_Goat, Shp_Sheep, Ch_Chicken, Dg_Dog., 


\section{Informant Consensus Factor (ICF) of the reported ethnoveterinary plants}

In this study we found the ICF values ranging from 0.75 to 0.92 . The Newcastle and respiratory ailments had the highest ICF value of 0.92 with 103 use-reports referring to the use of 9 plant species (Table 2). Other ailments categories include Jaundice (0.88), parasitic diseases $(0.87)$, brain and nervous system (0.80), gynaecological, andrological and urogenital (0.79), dermatological and related problems (0.79), gastrointestinal problems (0.78) and miscellaneous (0.75) for ailments were also reported by respondents (Table 2).

Table 2: Informant consensus factor for each livestock ailment categories

\begin{tabular}{lccc}
\hline Ailment categories treated & Nt & Nur & ICF \\
\hline Newcastle and respiratory diseases & 9 & 103 & 0.92 \\
Jaundice & 6 & 42 & 0.88 \\
Parasitic diseases & 10 & 69 & 0.87 \\
Brain and nervous system & 2 & 6 & 0.80 \\
Gynaecological, andrological and urogenital & 9 & 39 & 0.79 \\
Dermatological and related problems & & & \\
Gastrointestinal & 7 & 30 & 0.79 \\
Miscellaneous & 18 & 79 & 0.78 \\
\end{tabular}




\section{Fidelity Level (FL) of the reported ethnoveterinary plants}

The highest FL values for the fifteen most frequently reported plants were $C$. frutescens (Lam.) Benth (100.0) and K. africana L. (100.0) both responsible for treating Newcastle in Chicken, and F. sycomorus L. (100.0) for relieving birth complications in cattle. Other ethnoveterinary plants and their FL values were also reported as shown in Table 3.

Table 3. Fidelity level (FL) of frequently reported ethnoveterinary plants and livestock ailment category reported to prevent or treat.

\begin{tabular}{|c|c|c|c|c|}
\hline Scientific name & Ailment treated & Np & $\mathrm{Nu}$ & FL \\
\hline Capsicum frutescens L. & Newcastle & 13 & 13 & 100.0 \\
\hline Ficus sycomorus L. & Birth complications & 10 & 10 & 100.0 \\
\hline Kigelia africana (Lam.) Benth & Newcastle & 10 & 10 & 100.0 \\
\hline Euphorbia candelabrum Kotschy & Babesiosis & 8 & 10 & 80.0 \\
\hline Aloe vera (L.) Burm & Newcastle & 62 & 78 & 79.5 \\
\hline Aloe volkensii Engl. & Newcastle & 62 & 78 & 79.5 \\
\hline Croton microstachyus & Endoparasites & 11 & 16 & 68.8 \\
\hline Olea europaea L. & East Coast fever & 8 & 12 & 66.7 \\
\hline Cinchona officinalis L. & Trypanosomiasis & 9 & 14 & 64.3 \\
\hline Tithonia diversifolia (Hemsl.) A. Gray & Jaundice & 11 & 20 & 55.0 \\
\hline
\end{tabular}




\begin{tabular}{lllll} 
Ricinus communis L. & Loss of appetite & 6 & 11 & 54.5 \\
Rauvolfia caffra Sond. & Endoparasites, jaundice & 12 & 22 & 54.5 \\
Cordia africana Lam. & Lumpy skin disease & 10 & 19 & 52.6 \\
Azadirachta indica A. Juss. & Newcastle & 9 & 20 & 45.0 \\
& & & & 40.9 \\
Tetradenia riparia (Hochst.) Codd & Endoparasites & 9 & 22 & \\
\hline
\end{tabular}

\section{Discussion}

\section{Ethnoveterinary knowledge}

The knowledge on ethnoveterinary plants was found to vary based on gender, tribe, and type of livestock keeping system practices by respondents. This could be explained by the fact that animal keeping in Tanzania is culturally done by men rather than women and therefore, the transfer of ethnoveterinary knowledge is more obvious in men than women [11]. Previous studies show that men were more knowledgeable on ethnoveterinary practices in many areas [26,27]. Differences in knowledge across tribes is mainly attributed to their differing ways of sharing and maintaining knowledge, innovation and practices relating to the uses and management of plant resources [29]. This results in some tribes maintaining more knowledge than others. Systems of livestock keeping also affect the use of medicinal plants because differing systems expose livestock to infections to differing degrees. For example, cattle mobility in search of pasture and water predisposes animals to infections [30] more than zero grazing would. Factors such as high rate of infections and the failure to access healthcare services lead farmers using cattle mobility systems to opt for traditional plant remedies for preventing or controlling ailments in livestock. Contrary to that, livestock 
keepers practicing zero-grazing do not rely much on plant remedies due to good quality and nutritious feed, clean environment, reduced animal morbidity and interactions which eventually reduce exposure to zoonotic pathogens [31]. This, however, does not mean that livestock in zero grazing systems are void of ailments, they are also exposed to some infections [32,33].

\section{Ethnoveterinary plants used for treating livestock's ailments}

\section{Reported ethnoveterinary plants}

We found that the most used ethnoveterinary plants belong to Fabaceae, followed by Euphorbiaceae and Asteraceae families. Most plants in Fabaceae, Euphorbiaceae and Asteraceae families have been widely reported to possess medicinal properties for curing various ailments in human and livestock because of the presence of a wide variety of secondary metabolites [3,11]. Findings from this study are consistent with those obtained by [34] in the Northern regions of Ghana. On the other hand, members of the family Euphorbiaceae were also reported to possess veterinary values. Differential medicinal properties of the Euphorbiaceae are thought to be associated with its wide range of habitats which predispose plants in this family to high mutation loads hence the creation of defensive secondary metabolites which can have important healing properties [35]. In this study we also reported that, trees were the most commonly used life form. The high use value of trees could be attributed to the high richness and dominance of trees and agroforestry system practiced by inhabitants in the Northen Tanzania. This result matches the findings obtained by Muthee et al. [14], who found trees to contribute to the largest portion of the medicinal plants identified in Loitoktok in Kenya. 


\section{Parts of ethnoveterinary plant used, and methods of preparation and dosage administration}

Leaves were the most reported plant part used for preparation of medications for treating livestock ailments. High use value of leaves could be because harvesting of leaves is less destructive in comparison to harvesting roots and barks. This could be a strategy used by tribal people to conserve medicinal plants to ensure continuous supply. These findings are similar with those obtained by Amorim et al. [24] in Colares island in Brazil, Tariq et al. [26] in Sulaiman Range, Jayakumar et al. [2] of Konar community of Tamil Nadu and Kioko et al. [15] in Tanzania. Nevertheless, the use of leaves and other plant parts reported can pose severe threats to some rare and slowly reproducing plants if not identified and harvested sustainably. It is still premature to conclude that ethnoveterinary practices are conservation friendly. Further studies must be done to assess the quantity of plant parts harvested, dosage of medicine and status of these plants in the study area.

Further results show that most preparations were based on infusion (water-based preparation). This approach was commonly reported by respondents of this study as a means of preparing traditional dosage probably because of its effectiveness in making plant particles easily digestible and absorbed by the animals. These findings correspond to those obtained by Luseba and Tshisikhawe [5] on ethnoveterinary plants in South Africa. Also, we found that most recipes were formulated by plant materials purely obtained from a single plant species (monotherapy) as compared to polyherbal preparations (mixtures of more than one medicinal plant species). Results reported by Mussarat et al. [36] in Indus River depicted a similar pattern. A possible explaination for this practice could be due to the variation in indigenous knowledge across different ethnic groups involved in the study. Additives such as salts may also be added to ethnomedicine as a way to add tastes in the phytotherapies. Polyherbal preparation is common and has also been reported to be used in preparation of phytotherapies in other studies such as Eshetu et al. [10]. Oral route was 
found to be the most reported means of administering ethnomedicinal dosage. These findings are consistent with those of Eshetu et al. [10] on preparation and application methods of ethnoveterinary medicine by traditional healers, which was conducted in Southern Ethiopia and in Buuri district, Meru County in Kenya [37] .

\section{Quantitative indices for the reported ethnoveterinary plants}

The highest fidelity values for A. vera and A. volkensii are attributed by the pharmacological importance of the species of the family Asphodelaceae for curing different ailments in both humans and livestock [38] and have been widely reported to treat Newcastle in poultry. The highfidelity level for these species may have emerged from the fact that most people practicing poultry rearing are found where small scale poultry rearing practices acts as source of food and nutrition, as well as income and a way to improve their livelihoods [39]. Aloe spp are commonly used as laxatives, anti-inflammatories, immune-stimulant or antiseptics for healing and preventing various ailments in humans and livestock [40]. For instance, Aloe vera is used for supportive therapy and prophylaxis in commercial poultry production, treating internal and external injuries, and as purgative for ruminants in Trinidad and Tobago [41].

High ICF for Newcastle and respiratory category resulted from the use of A. vera and A. volkensii. Newcastle was reported to be a common poultry disease in the area, and so the knowledge of these plants' use is shared among people in curing the disease. This also means that there is a selection criterion in the medicine of these ailments and its usage information is well defined [24]. The miscellaneous category had low ICF because plants used to treat this ailment category are randomly chosen and thus informants do not exchange information about their use. This is also 
because this category had diseases which were not well-defined by livestock keepers, thus lacks a specific criterion for their selection.

High FLs were obtained for C. frutescens, $K$. africana and F. sycomorus. Pharmacological studies and reviews have been done for $C$. frutescens [42] where important bioactive compounds were isolated and studied for chickens infected with Newcastle disease $K$. africana [43] in which its effect on sperm quality of African Catfish was determined and it was found to possess promising pro-fertility which can be exploited in fish seeds production and F. sycomorus [44], whereby its stem bark revealed to possess alkaloids, flavonoids, glycosides, reducing sugars, resins, saponnins and tannins. Other studies need to be done to provide evidence for the efficacy of these useful plants in dealing with animal ailments. The medical efficacy of these plants with relatively high FL which include but not limited to E. candelabrum, A. vera, A. volkensii, C. microstachyus, $O$. europaea and C. officinalis need to be studied. Some studies have also been done on plants which have low FL in this study which include A. indica [45], and results have shown wound healing ability in both livestock and humans. Antimicrobial activity of T. riparia was assessed in a study by [46]. Similarly, $R$. caffra was also found to have antimicrobial and antioxidant activities in a study by Njau et al. [46] while C. africana was found to have anti-nociceptive activities [47].

\section{Conclusions}

In summary we found 54 plant species used in treatment of 34 livestock ailments by farmers in the study area. The Aloe vera, Aloe volkensii, Capsicum frutescens, Kigelia africana, and Ficus sycomorus were among the most commonly used species with the pharmacological importance of preventing or controlling various ailments in livestock in the study area. This study emphasizes a need to evaluate the pharmacological efficacy of the reported ethnoveterinary plants especially 
those with a high use values, and citations for treating a particular illness category. This might provide potential leads in fulfilling the unmet needs in animal husbandry in rural Tanzania. Overall, high use of ethnoveterinary remedies in healing ailments in livestock highlights the need of government support for initiatives aimed at preserving this knowledge as an alternative livestock healthcare practices especially for farmers residing in areas where shortage of synthetic drugs, lack of skilled veterinarians, and low financial capacity of farmers to pay for modern veterinary services exist. 


\section{Ethics approval and consent to participate}

Letters of consent were taken from the Department of Research and Consultancy at College of African Wildlife Management, Mweka and in each sampled district, the office of District Executive Director was informed prior to the data collections. Oral consents were also obtained from the informants before the interviews and questionnaire administering.

\section{Consent for publication}

Not applicable.

\section{Availability of data and material}

The datasets used and/or analyzed during the current study are available from the corresponding author on reasonable request.

\section{Competing interests}

The authors declare that they have no competing interests

\section{Funding}

This research received no specific grant from funding agencies in the public, commercial, or notfor-profit sectors.

\section{Authors' contributions}

TT, RM, AM and AWK conceptualized a research and its design; TT collected and compiled the data; TT, RM and JS performed the analysis; TT and RM wrote an original draft; and all authors contributed in review and approved the final manuscript. 


\section{Acknowledgements}

Authors would like to thank the College of Wildlife Management, Mweka for providing necessary resources which helped to meet field logistics and completion of this study. We are also grateful to Mariam Khatibu for describing livestock ailments based on the symptoms described by the informants. We also thank all respondents who shared their precious, and valuable information that made this study a success. Special thanks to Willow Sommer and Alicia Bailey for English editing. 


\section{References}

1. Abo-el-sooud K. Ethnoveterinary perspectives and promising future. Int J Vet Sci Med. 2018;6: 1-7. doi:10.1016/j.jjvsm.2018.04.001

2. Jayakumar S, Baskaran N, Arumugam R, Sathiskumar S, Pugazhenthi M. Herbal medicine as a live practice for treating livestock ailments by indigenous people: A case study from the Konar community of Tamil Nadu. South African J Bot. 2018;118: 23-32. doi:10.1016/j.sajb.2018.06.002

3. Amri E, Kisangau DP. Ethnomedicinal study of plants used in villages around Kimboza forest reserve in Morogoro, Tanzania. J Ethnobiol Ethnomed. 2012;8: 1. doi:10.1186/17464269-8-1

4. Shen S, Qian J, Ren J. Ethnoveterinary plant remedies used by Nu people in NW Yunnan of China. J Ethnobiol Ethnomed. 2010;6: 1-10. doi:10.1186/1746-4269-6-24

5. Luseba D, Tshisikhawe MP. Medicinal plants used in the treatment of livestock diseases in Vhembe region, Limpopo province, South Africa. J Med Plants Res. 2013;7: 593-601. doi:10.5897/JMPR12.1213

6. Gazzaneo LRS, Paiva de Lucena RF, de Albuquerque UP. Knowledge and use of medicinal plants by local specialists in an region of Atlantic Forest in the state of Pernambuco (Northeastern Brazil). J Ethnobiol Ethnomed. 2005;1: 1-8. doi:10.1186/1746-4269-1-9

7. Ijaz F, Iqbal Z, Rahman IU, Alam J, Khan SM, Shah GM, et al. Investigation of traditional medicinal floral knowledge of Sarban Hills, Abbottabad, KP, Pakistan. J Ethnopharmacol. 2016;179: 208-233. doi:10.1016/j.jep.2015.12.050 
8. Jamila F, Mostafa E. Ethnobotanical survey of medicinal plants used by people in Oriental Morocco to manage various ailments. J Ethnopharmacol. 2014;154: 76-87. doi:10.1016/J.JEP.2014.03.016

9. Chinsembu KC, Negumbo J, Likando M, Mbangu A. An ethnobotanical study of medicinal plants used to treat livestock diseases in Onayena and Katima Mulilo , Namibia. South African J Bot. 2014;94: 101-107. doi:10.1016/j.sajb.2014.06.007

10. Eshetu GR, Dejene TA, Telila LB, Bekele DF. Ethnoveterinary medicinal plants: Preparation and application methods by traditional healers in selected districts of southern Ethiopia. Vet world. 2015;8: 674-684. doi:10.14202/vetworld.2015.674-684

11. Giday M, Asfaw Z, Woldu Z. Medicinal plants of the Meinit ethnic group of ethiopia: An ethnobotanical study. J Ethnopharmacol. 2009; 9. doi:10.1016/j.jep.2009.05.009

12. Maroyi A. Use of traditional veterinary medicine in Nhema communial area of the midlands province, Zimbabwe. African Networks on Ethnomedicines. 2012;9: 315-322. doi:10.4314/ajtcam.v9i3.3

13. Odugbemi TO, Akinsulire OR, Aibinu IE, Fabeku PO. Medicinal plants useful for malaria therapy in Okeigbo Ondo State, SouthWest Nigeria. Int J Child Spiritual. 2004;9: 97-104. doi:10.1080/1364436042000200852

14. Muthee JK, Gakuya DW, Mbaria JM, Kareru PG, Mulei CM, Njonge FK. Ethnobotanical study of anthelmintic and other medicinal plants traditionally used in Loitoktok district of Kenya. J Ethnopharmacol. 2011;135: 15-21. doi:10.1016/j.jep.2011.02.005

15. Kioko J, Baker J, Shannon A, Kiffner C. Ethnoecological knowledge of ticks and treatment 
of tick-borne diseasesamong maasai people in northern Tanzania. Vet World. 2015;8: 755762. doi:10.14202/vetworld.2015.755-762

16. Minja MM. Medicinal plants used in the promotion of animal health in Tanzania. Rev Sci Tech. 1994;13: 905-925. doi:10.20506/rst.13.3.800

17. Nahashon M. Conservation of Wild-harvested Medicinal Plant Species in Tanzania: Chain and consequence of commercial trade on medicinal plant species. 2013.

18. Martínez GJ, Luján MC. Medicinal plants used for traditional veterinary in the Sierras de Córdoba ( Argentina ): An ethnobotanical comparison with human medicinal uses. J Ethnobiol Ethnomed. 2011;7: 23. doi:10.1186/1746-4269-7-23

19. Pande P, Tiwari L, Pande H. Ethnoveterinary plants of Uttaranchal - A review. Indian J Tradit Knowl. 2007;06: 444-458.

20. Maregesi SM, Mwakalukwa R. Ethnopharmacological Study on Medicinal Plants Used to Treat Infectious Diseases in the Rungwe District, Tanzania. Int J Med plants Nat Prod. 2015;1: 15-23.

21. Khan B, Abdukadir A, Qureshi R, Mustafa G. Medicinal uses of plants by the inhabitants of Khunjerab national park, Gilgit, Pakistan. Pakistan J Bot. 2011;43: 2301-2310.

22. Hamisy WC, Mwaseba D, Zilihona I., Mwihomeke S. Status and domestication potential of medicinal plants in the Uluguru Mountain area, Tanzania. 2000.

23. Alexiades MN. Collecting Etnobotanical Data: An Introduction to Basic Concepts and Techniques. Selected Guidelines for ethnobotanical Research: A Field Manual. 1996. pp. 53-94. 
24. Amorim R, Vivina M, Monteiro B, Ozanan F, Monteiro B, Rodrigues T, et al. Ethnoveterinary knowledge and practices at Colares island, Para eastern Amazon, Brazil. J Ethnopharmacol. 2012;144: 346-352. doi:10.1016/j.jep.2012.09.018

25. R Core Development Team. A language and environment for statistical computing. R Foundation for Statistical Computing,. Vienna, Austria.: R Foundation for Statistical Computing; 2018. Available: https://www.r-project.org/

26. Tariq A, Mussarat S, Adnan M, Abdelsalam NM, Ullah R, Khan AL. Ethnoveterinary Study of Medicinal Plants in a Tribal Society of Sulaiman Range. Sci World J. 2014;2014: 10. doi:10.1155/2014/127526

27. Tumoro G, Maryo M. Determination of informant consensus factor and fidelity level of ethnomedicinal plants used in Misha. Int J Biodivers Conserv. 2016;8: 351-364. doi:10.5897/IJBC2016.1020

28. Uddin mohamed Z, Hassan A. Determination of informant consensus factor of ethnomedicinal plants used in kalenga forest, bangladesh. Bangladesh Assoc Plant Taxon. 2014;21: 83-91.

29. Davis M. The protection of Indigenous knowledge. Biological Diversity and Indigenous Knowledge. 2008. pp. 211-228.

30. Alhaji NB, Babalobi OO, Isola TO. A quantitative exploration of nomadic pastoralists ' knowledge and practices towards Rift Valley fever in Niger State, North-central Nigeria : The associated socio-cultural drivers. One Heal. 2018;6: 16-22. doi:10.1016/j.onehlt.2018.09.001 
31. Sudda M. Animal health management practices in zero grazing dairy units in Arusha city, Tanzania. African J food, Agric Nutr Dev. 2017;17: 12904-12915. doi:10.18697/ajfand.80.16775

32. Nguhiu-Mwangi J, Mbithi PMF, Wabacha JK, Mbuthia P. Risk (Predisposing) Factors for Non-Infectious Claw Disorders in Dairy Cows Under Varying Zero-Grazing Systems. A Bird's-Eye View Vet Med. 2012; 393-. doi:10.5772/29795

33. Tomley FM, Shirley MW. Livestock infectious diseases and zoonoses. Philos Trans R Soc B Biol Sci. 2009;364: 2637-2642. doi:10.1098/rstb.2009.0133

34. Ziblim IA, Timothy KA, Deo-Anyi EJ. Exploitation and use of medicinal plants, Northern Region, Ghana. J Med Plants Res. 2013;7: 1984-1993. doi:10.5897/jmpr12.489

35. Moshi MJ, Otieno DF, Weisheit A. Ethnomedicine of the Kagera Region, north western Tanzania . Part 3 : plants used in traditional medicine in Kikuku village, Muleba District. J Ethnobiol Ethnomed. 2012;8: 14. doi:10.1186/1746-4269-8-14

36. Mussarat S, Amber R, Tariq A, Adnan M, AbdElsalam NM, Ullah R, et al. Ethnopharmacological assessment of medicinal plants used against livestock infections by the people living around Indus river. Biomed Res Int. 2014;2014. doi:10.1155/2014/616858

37. Gakuubi MM, Wanzala W. A survey of plants and plant products traditionally used in livestock health management in Buuri district, Meru County, Kenya. J Ethnobiol Ethnomed. 2012;8: 1-19. doi:10.1186/1746-4269-8-39

38. Mbambo B, Odhav B, Mohanlall V. Antifungal activity of stigmasterol, sitosterol and ergosterol from Bulbine natalensis Baker (Asphodelaceae). J Med Plants Res. 2012;6: 
5135-5141. doi:10.5897/jmpr12.151

39. Guèye EF. The role of family poultry in poverty alleviation, food security and the promotion of gender equality in rural africa. Outlook Agric. 2000;29: 129-136. doi: $10.5367 / 000000000101293130$

40. Avasthi S, Gautam AK, Bhadauria R. First report of anthracnose disease of Aloe vera caused by Colletotrichum gloeosporioides Dates. J Res Biol. 2011;1: 408-410.

41. Lans C, Brown G. Ethnoveterinary medicines used for ruminants in Trinidad and Tobago. Prev Vet Med. 1998;35: 149-163. doi:10.1016/S0167-5877(98)00066-X

42. Al-snafi AE. The pharmacological importance of capsicum species (capsicum annuum and capsicum frutescens) grown in iraq. J Pharm Biol. 2019;5: 124-142.

43. Adeparusi EO. Effects of Medicinal Plant ( Kigelia Africana ) on Sperm Quality of African Catfish Clarias Gariepinus ( Burchell , 1822 ) Broodstock. J Agric Sci. 2010;2: 193-199.

44. Oluwasesan BM, Agbendeh ZM, Adikwu JG. Comparative studies of phytochemical screening of Ficus sycomorus linn stem bark extract and Piliostigma thonningii roots extract. Asian J Plant Sci Res. 2013;3: 69-73.

45. Ranjit RR, Yogesh more W, Aparna taware s. Review On Biological Activities Of Azadirachta Indica ( Neem ) and its Medicinal Uses. Int J Inf Futur Res. 2015;2: 13271334.

46. Njau EA, Alcorn J, Ndakidemi P, Chirino-trejo M, Buza J. Antimicrobial and antioxidant activity of crude extracts of Rauvolfia caffra var. caffra (Apocinaceae) from Tanzania. Int J Biol. 2014;6: 156-167. doi:10.5539/ijb.v6n4p156 
47. Tijjani RG, Umar ML, Hussaini IM, Shafiu R, Zezi AU. Anti-nociceptive activities of the ethanolic stem bark extract of Cordia Africana ( Boraginaceae ) in rats and mice. Ann Biol Sci. 2016;4: 6-12. 


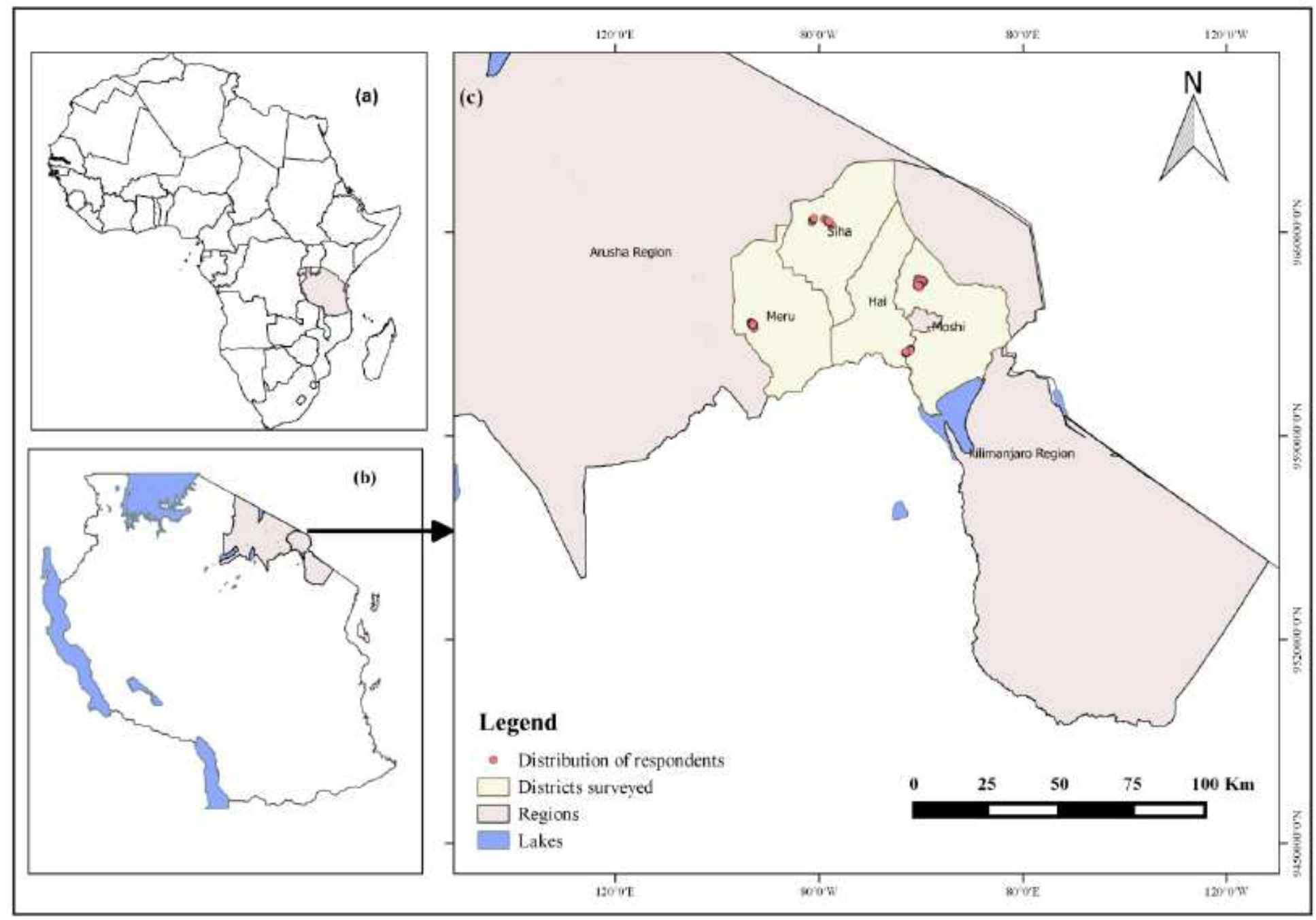

Figure 1

A Map of the study area showing study sites. (a) Location of Tanzania on the map of Africa; (b) Location of the surveyed area on the map of Tanzania (c) Distribution of respondents in Moshi, Hai, Siha and Meru districts in the Northern Tanzania. Note: The designations employed and the presentation of the material on this map do not imply the expression of any opinion whatsoever on the part of Research Square concerning the legal status of any country, territory, city or area or of its authorities, or concerning the delimitation of its frontiers or boundaries. This map has been provided by the authors. 


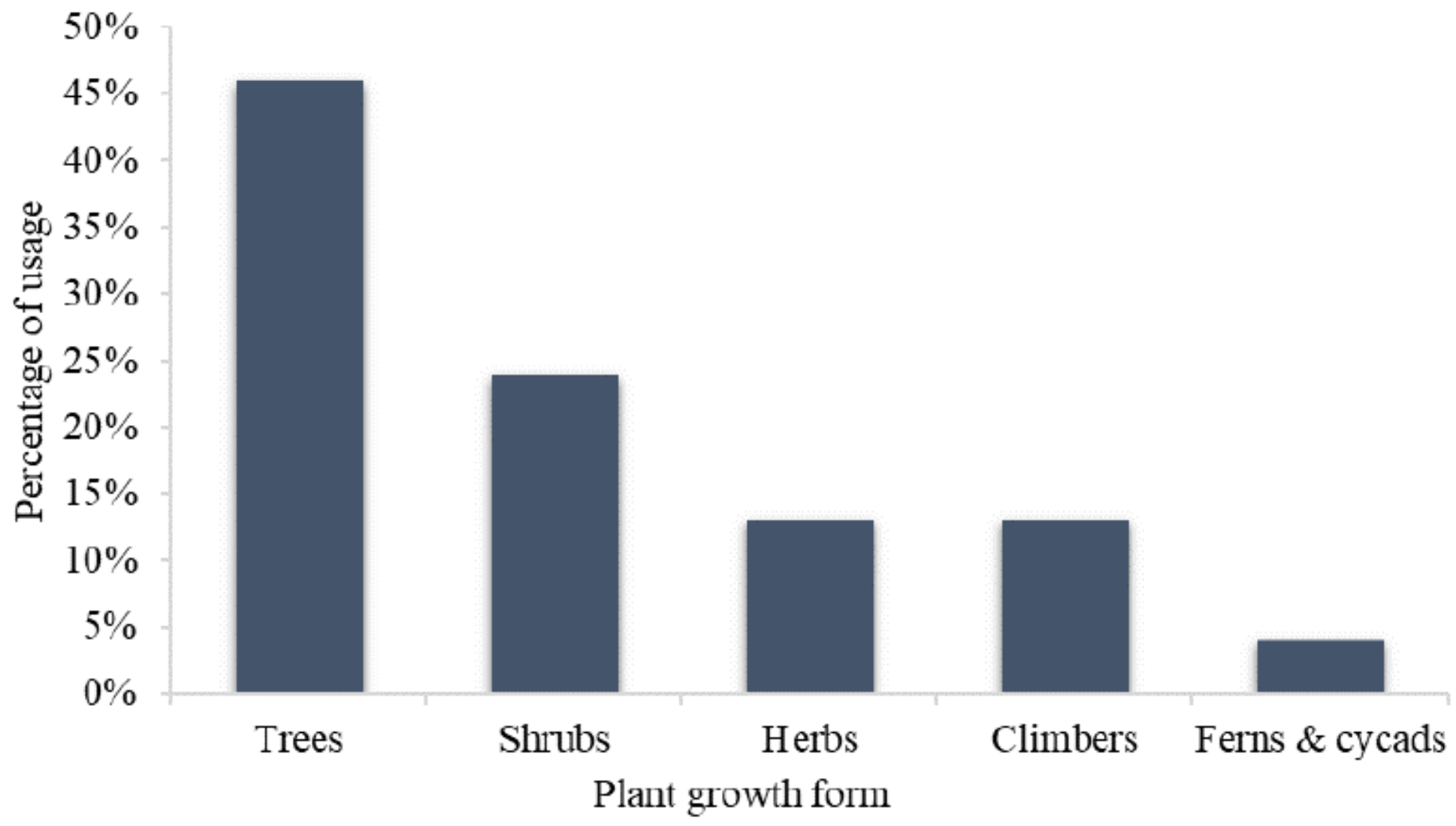

Figure 2

Distribution of plants into different life forms. Bars show the percentage of identified ethnoveterinary plants in each growth habit category. 


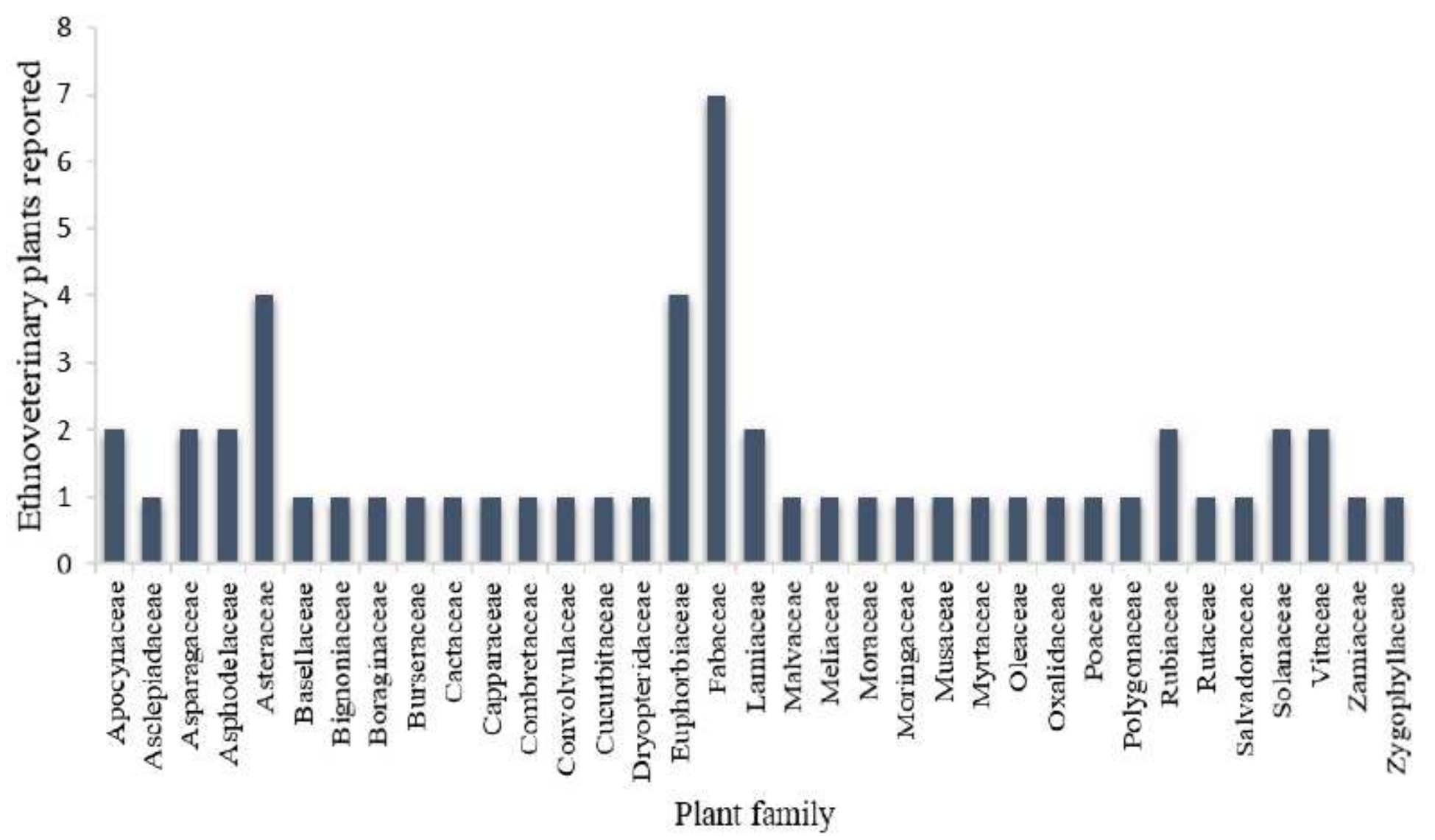

Figure 3

Distribution of plants in different families. Bars indicate family and number of ethnoveterinary plants reported. 


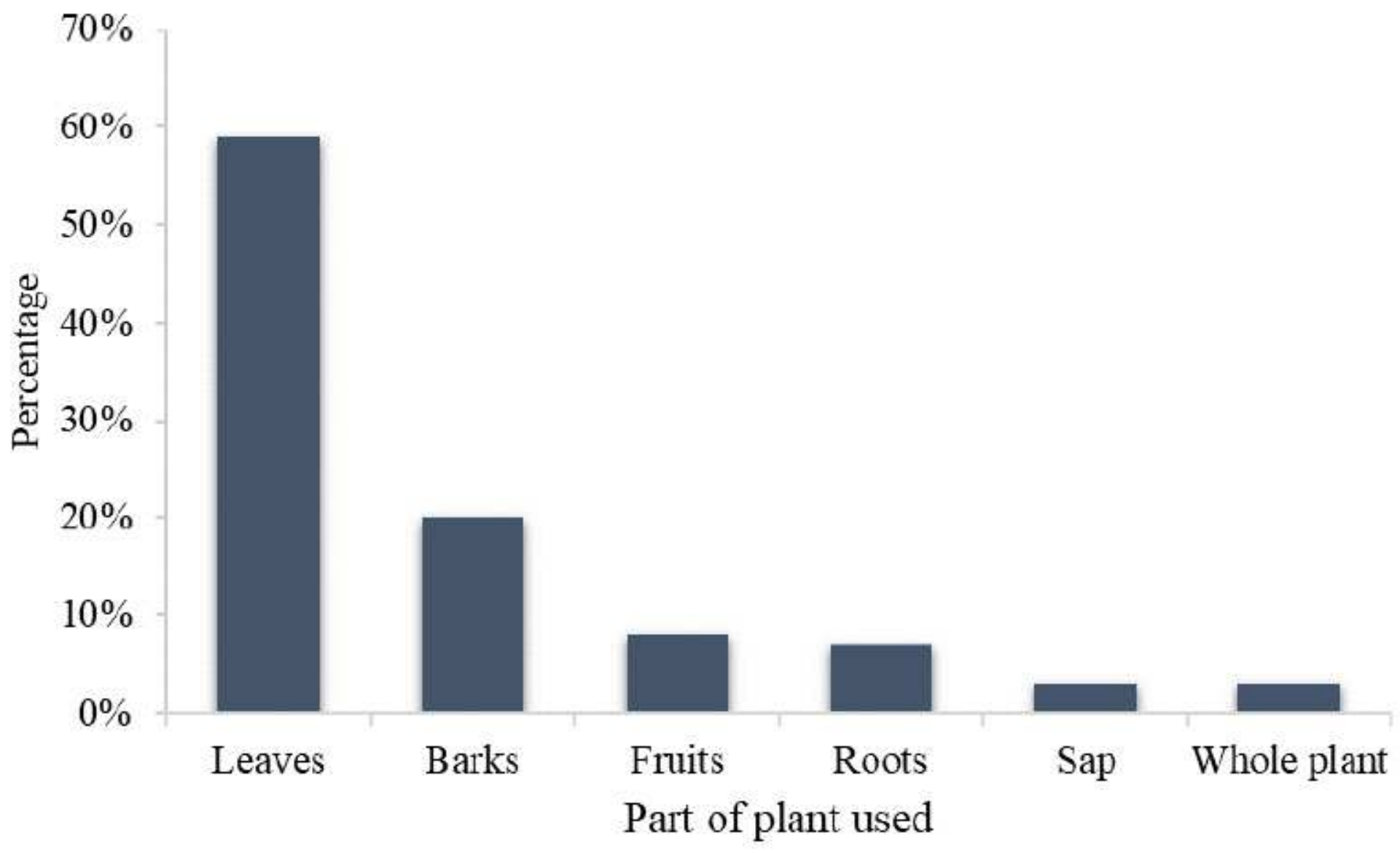

Figure 4

Parts of plant used for preparing a traditional medicine and percentage of usage in treating or preventing livestock ailments.

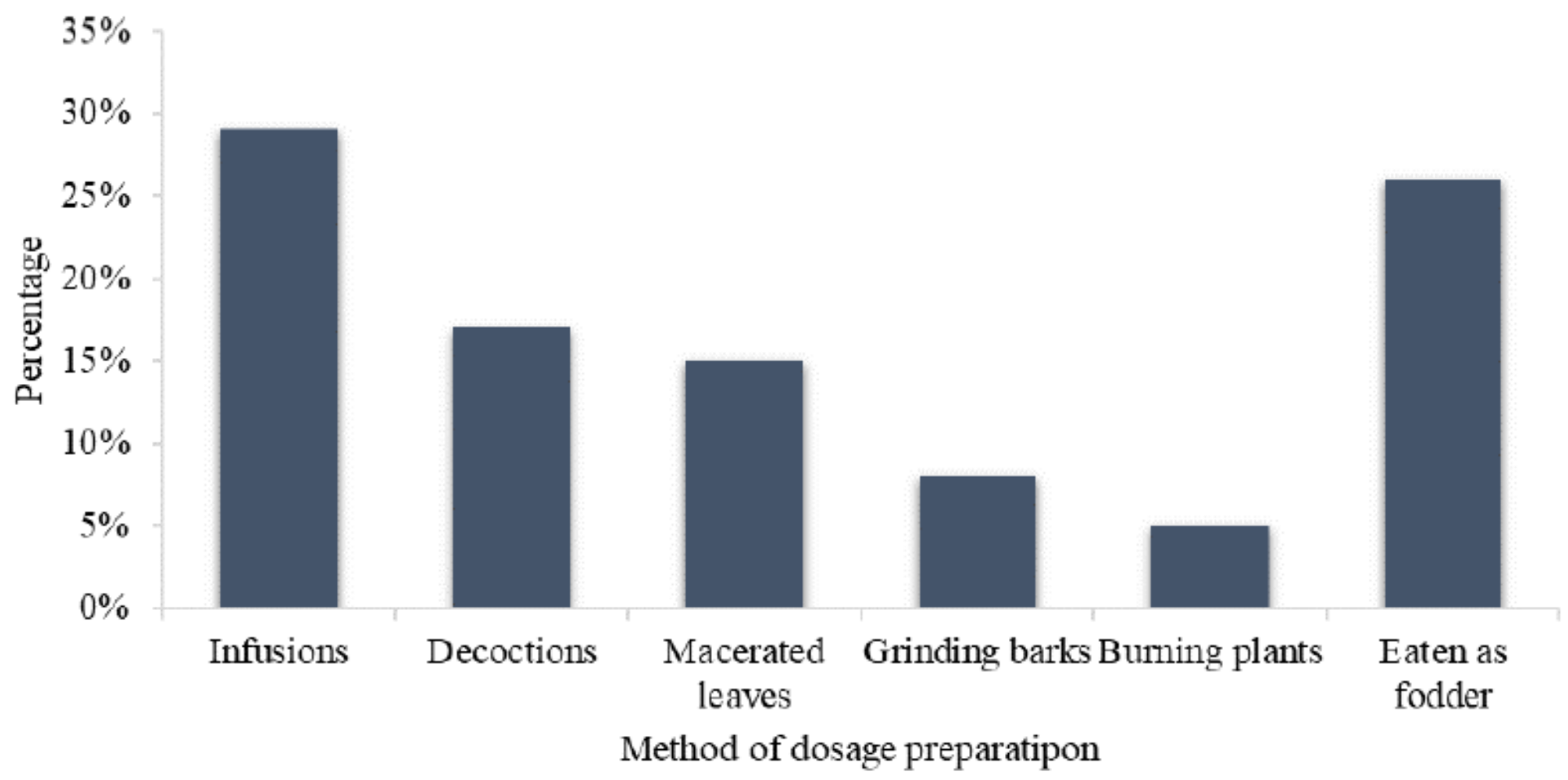


Figure 5

Methods of preparing traditional phytotherapy, and percentage of respondent's citations by livestock keepers.

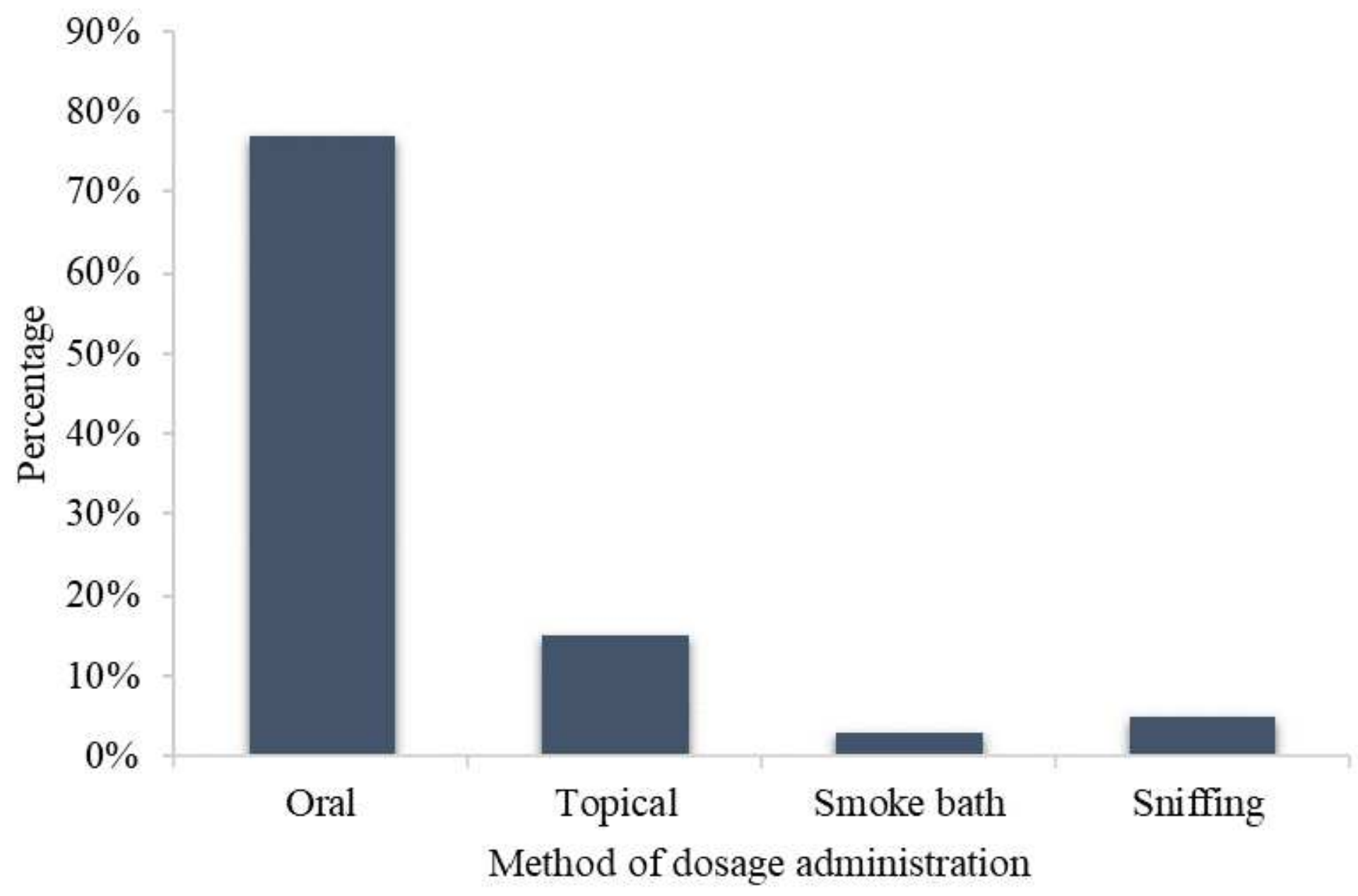

Figure 6

Methods of dosage administration. Bars show the percentage of respondent's citations for a particular method of administering traditional medications. 